\title{
High-resolution 3D geological model of the bauxite-bearing area Crvene Stijene (Jajce, Bosnia and Herzegovina) and its application in ongoing research and mining
}

\author{
Ivica PAVIČIĆ ${ }^{1, *}$, Ivan DRAGIČEVIĆ ${ }^{1}$ and Ivona IVKIĆ ${ }^{1}$ \\ 1 University of Zagreb, Faculty of Mining, Geology and Petroleum Engineering, Department of Geology and Geological \\ Engineering, Pierottijeva 6, 10000 Zagreb, Croatia
}

Pavičić, I., Dragičević, I., Ivkić, I., 2018. High-resolution 3D geological model of the bauxite-bearing area Crvene Stijene (Jajce, Bosnia and Herzegovina) and its application in ongoing research and mining. Geological Quarterly, 62 (1): 100-119, doi: $10.7306 / g q .1396$

\begin{abstract}
Three-dimensional (3D) geological models are useful tools in various geological, mining and other engineering activities. Geological model shows stratigraphic, structural and lithologic settings of the study area in 3D space, and serves as a 3D geodatabase for a variety of input data. The study area is one of the bauxite-bearing sites, Crvene Stijene, near Jajce (Bosnia and Herzegovina). During the last decades, a number of geological, geodetic, mining and other data were collected through intensive geological research and mining (exploration), with the aim of finding and exploiting bauxite deposits. Therefore, selected area is a great polygon for the implementing and testing of workflow for the construction of a 3D geological model of bauxite-bearing field and its application in current and future research and mining. Presented workflow includes collection, digitalization, organization and visualization for different types of existing and new data (600 boreholes, geological maps and cross-sections, DEM, structural measurements from the surface, as well as in tunnels and adits) in 3D geological database. For this study, different types of geological objects, fault planes and geological surfaces were modelled with different interpolation algorithms. The constructed model is interactive and it can be easily updated by new input data from current research and exploitation activities: boreholes, underground mining objects, etc. The 3D geological model represents a relevant foundation for planning new research and mining activities. Furthermore, newly found deposits and their volumes can be quickly modelled, contoured and calculated. Presented modelling workflow is applicable to other areas and other mineral resources.
\end{abstract}

Key words: 3D geological modelling, Ordinary Kriging, bauxites, Midland Valley Move, Jajce, Bosnia and Herzegovina.

\section{INTRODUCTION}

Geological models represent a solid background, not only for the visualization of geological data in two and three dimensions, but also for data acquiring, processing and organizing them into the geodatabase (Wu et al., 2005). Models are usually based on stratigraphic and structural settings (presented in stratigraphic columns, various geological maps and cross-sections), measured structural elements on the surface and in underground mining objects (adits, tunnels), geodetic and geophysical data, and boreholes (Zehnder and Allmendinger, 2000; Sirakov and Muge, 2001; Lemon and Jones, 2003; Wu et al., 2005). Application of 3D geological modelling is widely used in hydrocarbon exploration (e.g., Chiles et al., 2004; Perrin et al., 2005; Kaufmann and Martin, 2008). The development of the computer industry and software for 3D geological modelling introduces the opportunity for their application in other fields of geology as well (Xue et al., 2004; Kaufmann and Martin, 2008).

\footnotetext{
* Corresponding author, e-mail: ivica.pavicic@rgn.hr

Received: September 1, 2017; accepted: November 12, 2017; first published online: January 18, 2018.
}

To date, many authors have dealt with the different challenges in constructing 3D geological models:

- the methodology of constructing a 3D geological model based on various input data (Mallet 1992, 1997, 2002; de Kemp, 1999, 2000; Husson and Mugnier, 2003; Lemon and Jones, 2003; Maxelon and Mancktelow, 2005; Sprague and de Kemp, 2005; Dhont et al., 2005; de Kemp et al., 2006; Zhu et al., 2006; Frank et al., 2007; Caumon et al., 2009; Zanchi et al., 2009);

- modelling of regional geological structures (Ledru, 2001 and references therein; Courrioux et al., 2001; Galera et al., 2003; Wu et al., 2005; Zanchi et al., 2009; Snidero et al., 2011; Popovs et al., 2015);

- modelling of local structures and/or mineral deposits (Fernández et al., 2004; Kaufmann and Martin, 2008; Wycisk et al., 2009; Schetsellar, 2013; Vanneschi et al., 2014, Martin-Izard et al., 2015; Basson et al., 2016).

In order to plan mining activities for the exploitation of mineral resources, it is required to define geological structure of the area, and the spatial distribution and geometry of ore deposits and waste rock. Lack of thorough geological exploration usually leads to difficulties in the design and construction of mining objects (Vanneschi et al., 2014). The consequences could be numerous technological problems during the construction, such as a threat to human lives, machinery damage and an increase 


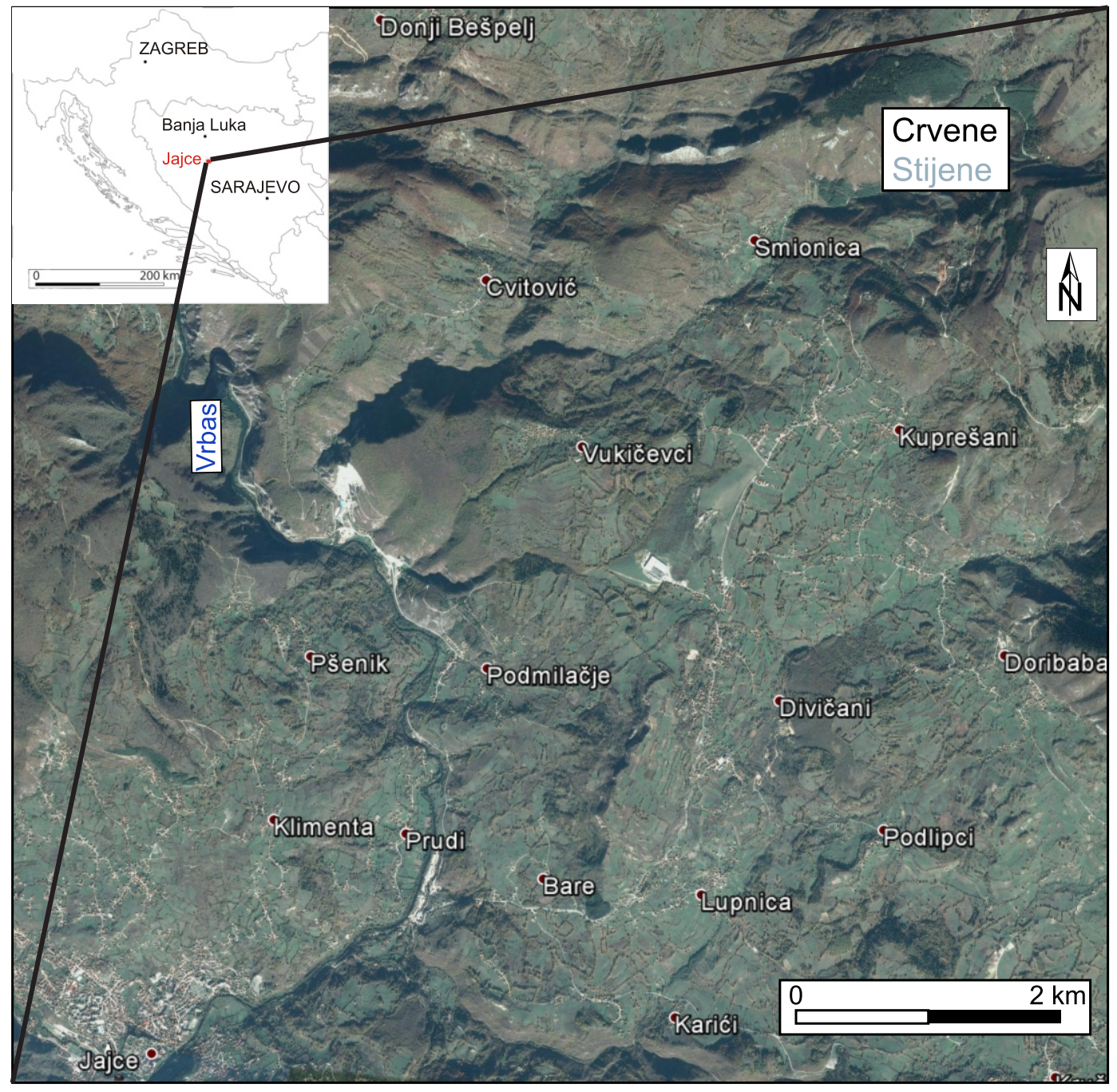

Fig. 1. Geographical location of the bauxite-bearing area Crvene Stijene, Jajce (Bosnia and Herzegovina)

in financial cost of the mining object. With enough input data, 3D models can represent very accurately the geological structure of the area (Caumon et al., 2009; Vanneschi et al., 2014). Models are especially useful when the ore bodies are in geologically complex structures and/or when they are located at a great depth. They can also be useful for more efficient planning of future research and mining activities.

In this paper, the workflow for constructing a 3D geological model of the bauxite-bearing area Crvene Stijene (Jajce, Bosnia and Herzegovina) is presented with the application for ongoing geological research and mining (see Figs. 1 and 2A). The Crvene Stijene area is geologically very thoroughly investigated. All bauxite deposits are underground at depths of $20 \mathrm{~m}$ or more. Almost all of the modelled bauxite deposits are already completely exploited, so the area represents a solid polygon for 3D geological modelling and analysis of interpolation algorithms. Available input data includes: stratigraphically defined footwall (palaeorelief) and hanging-wall of bauxite deposits, regional geological maps (scale 1:25,000), detailed geological maps (1:1000) of individual deposits, geological cross-sections, topographic maps (scale 1:25,000, 1:1000), >600 boreholes, and $>10 \mathrm{~km}$ of underground mining objects (adits and tunnels). Adits and tunnels needed to be geologically mapped (faults and palaeorelief surface - i.e. the contact between footwall and hanging-wall to bauxite deposits).
The model includes: fault planes, footwall surface of bauxite deposits, i.e. palaeorelief, top surfaces of bauxite deposits, and solid models (individual bauxite bodies) of bauxite deposits. Different geological surfaces (faults, palaeorelief, bauxite hanging-wall surfaces) were covered by a different type, density and quality of input data. It was necessary to combine input data with different interpolation algorithms to ensure the reliability of the model. Since solid models of individual bauxite deposits were built, it was easier to determine their type, maximum length, width, thickness and volume. Constructed 3D geological models can represent the basis for models of other bauxite-bearing areas and/or models of other raw mineral resources.

\section{GEOLOGICAL SETTINGS}

The bauxite-bearing area Jajce (Fig. 1) includes a number of sites with numerous bauxite deposits and occurrences of Upper Albian to Santonian-Maastrichtian age. The Jajce area, from a regional geological perspective, is a part of the northeastern margin of the Adriatic Carbonate Platform that existed from end-Early Jurassic to end-Early Cretaceous times (Dragičević, 1987; Dragičević and Velić, 2002).

The fundamental stratigraphic and tectonic features were defined in the Basic Geological Map of Yugoslavia, sheet Jajce, 
1:100,000 (Marinković and Ahac, 1975), explanatory notes for that map (Marinković and Đorđević, 1975), and on the geological maps of bauxite-bearing area Jajce, 1: 25,000 (Dragičević, 1981; Papeš, 1984). To date, there has been a variety of published and unpublished geological research papers (e.g., Tomić, 1983; Dragičević, 1987, 1997; Dragičević and Velić, 1994, 2002, 2006; Moro et al., 2016).

The oldest rocks present in the area are shallow-marine, finely layered white to grey limestones of Early Cretaceous age, which end with Albian shallow-marine white-light grey to pink limestones. The end of the Early Cretaceous and the beginning of the Late Cretaceous on the carbonate platform margin were characterized by intense compressional tectonics and emersion of regional impact (Dragičević, 1987; Dragičević and Velić, 2002). The emersion lasted from the Late Albian to the Santonian-Maastrichtian, $\sim 20$ My. During that period, bauxites formed on the diversified palaeorelief surface (footwall to bauxite deposits) in the study area (Fig. 2). They represent a typical terrestrial formation. Bauxite deposits are of di- verse shape and size, which was predetermined by the palaeorelief morphology. Through post-platform tectonic processes (folding and faulting), the deposits were brought to the present structural position.

The stratigraphic hanging-wall of the bauxite deposits is composed mainly of carbonate clastics. Lithologically, this clastic rocks are represented by numerous and diverse lithofacies types. The most common are carbonate breccia, conglobreccia and conglomerates (Fig. 3), but there are also, layers of calcarenite, argillaceous micrite and marl in the lithological column. Frequent vertical and lateral changes of these lithofacies are common (see the geological column in Fig. 4). The basal part of the hanging-wall transgressive member regularly contains coarse-grained lithotypes (they are transgressive and relatively concordant with the bauxite deposits and the shallow-marine shelf carbonates). Younger sequences of hanging-wall sediments show features of basinal sedimentation, i.e. a rhythmical alternation of coarse- and fine-grained carbonate clastics with a regular presence of pelagic limestones. The sedi-

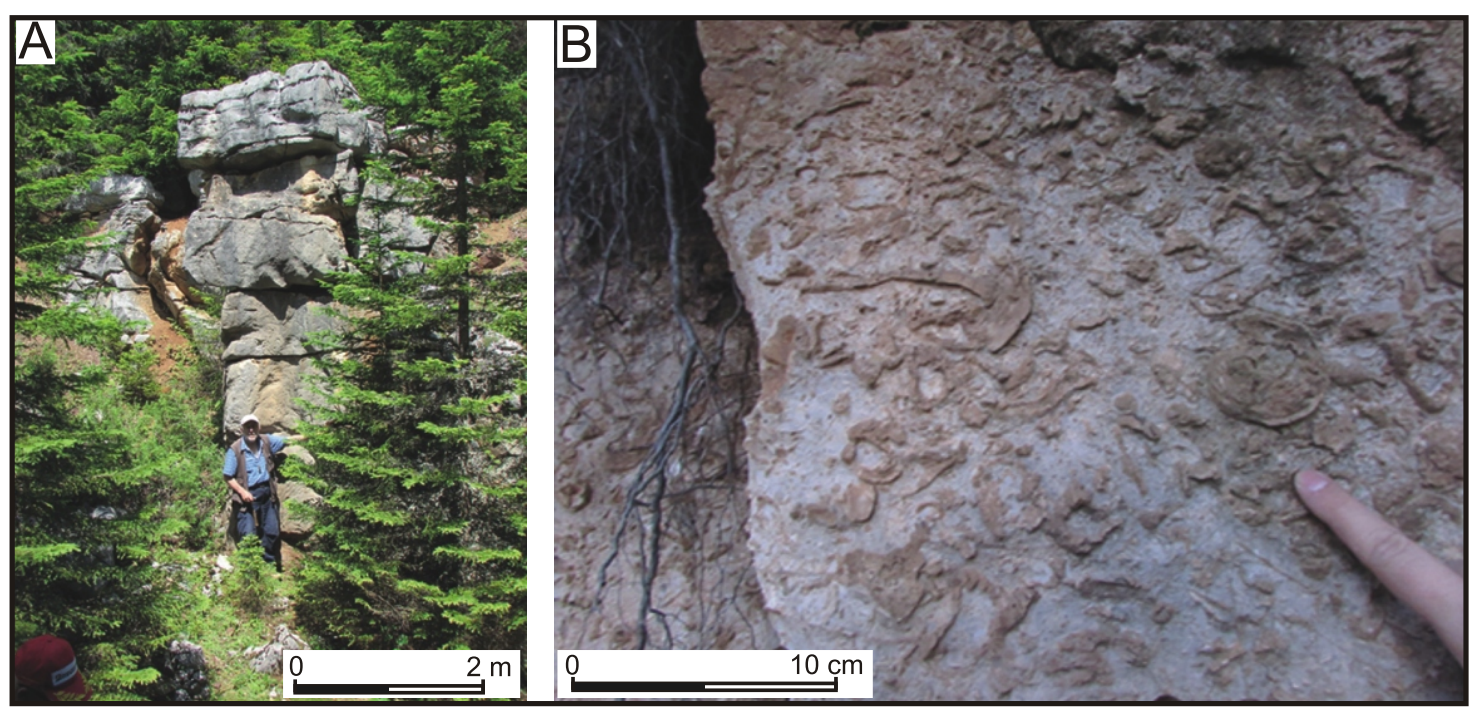

Fig. 2. Albian limestones - footwall to bauxite deposits

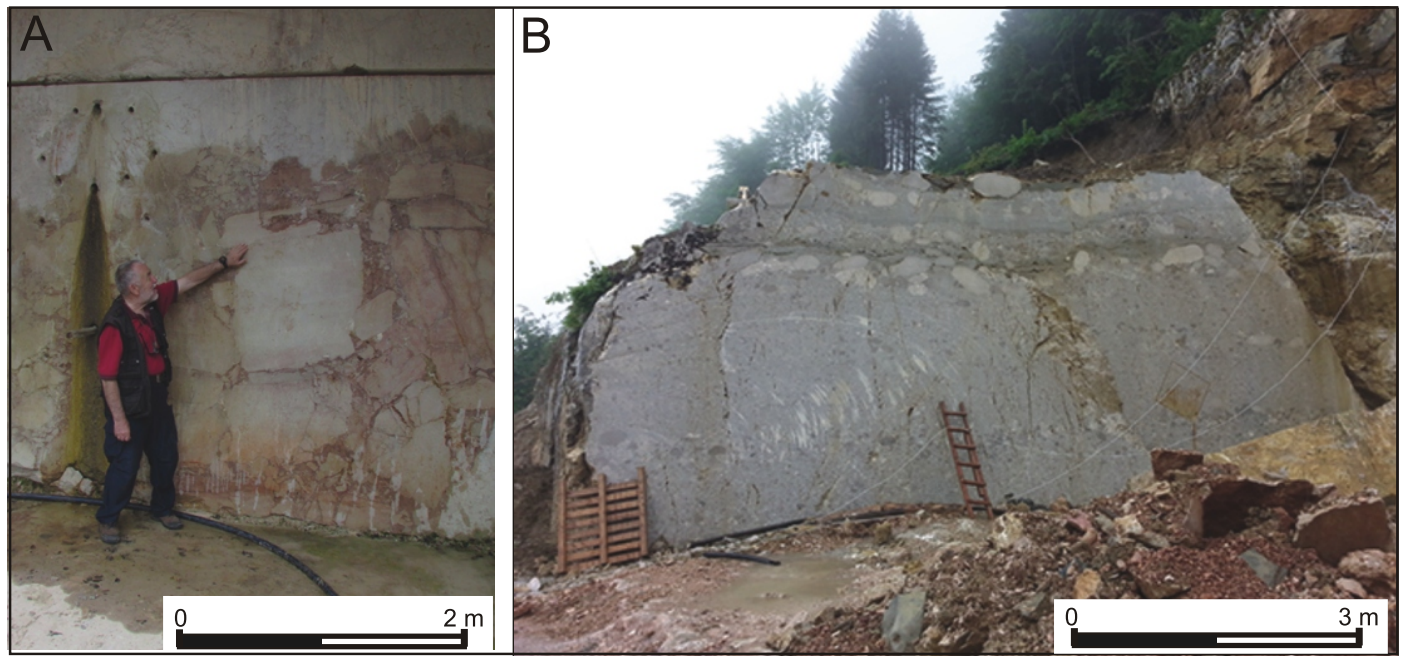

Fig. 3. Upper Cretaceous breccias and conglomerates - hanging-wall of bauxite deposits 


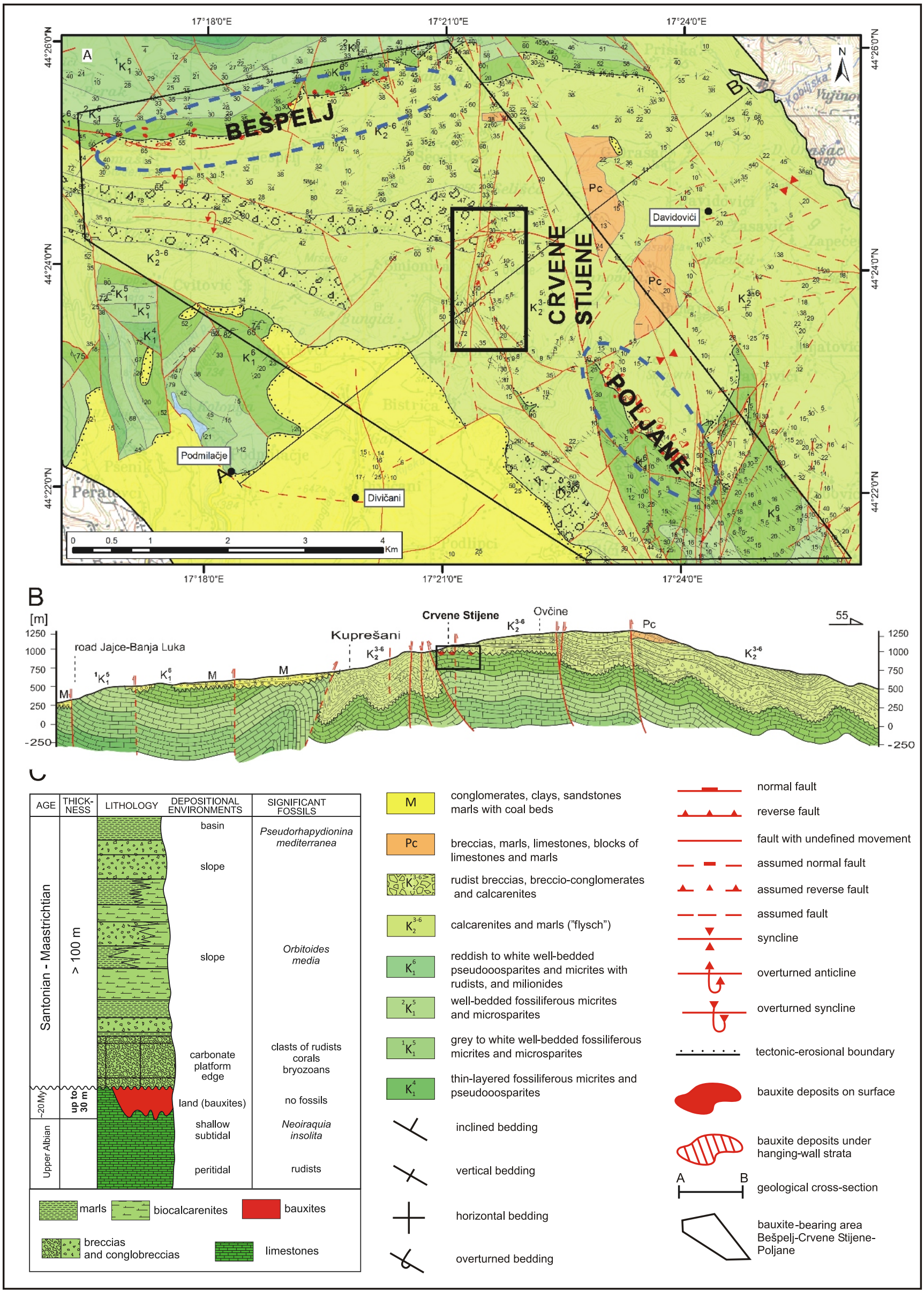

Fig. 4A - geological map of the bauxite-bearing area Jajce (Dragičević, 1981; Papeš, 1984); B - geological cross-section through the Crvene Stijene area (Dragičević, 1981); C - detailed geological column of the Crvene Stijene bauxite deposits 

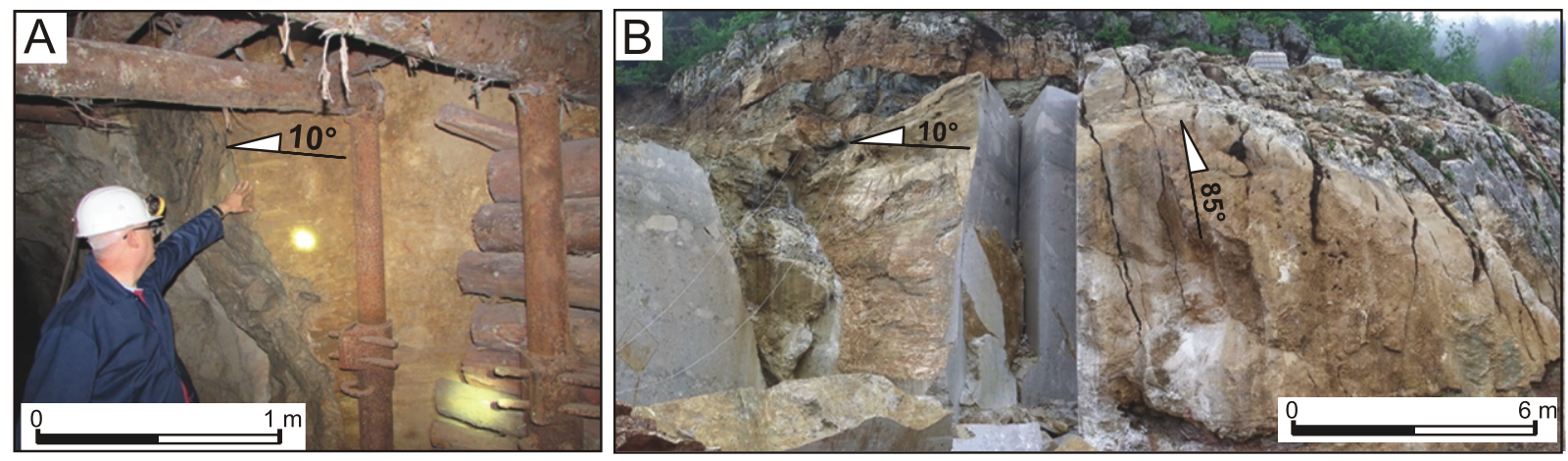

Fig. 5. Crvene Stijene-Bešpelj Fault (CSB a in Fig. 6) measured in two placemarks

$$
\text { A - in adit K-900 (PI-1 in Fig. 6), B - in the outcrop (PI-2 in Fig. 6) }
$$

mentation mechanism was by turbidity currents, as indicated by numerous textures that are characteristic for turbidite sediments.

The present-day geological settings of the area are the result of post-platform structural-tectonic changes, which began at the end of the Cretaceous period and continue in the present (Dragičević, 1981, 1987; Dragičević and Velić, 2002).

The major structural features of the Crvene Stijene structure are faults (Figs. 4-6). The structure is bounded by the Crvene Stijene-Bešpelj Fault Zone on the west side (CSB in Fig. $6 ; 125^{\circ} / 80^{\circ} / 10^{\circ}$ - left reverse), which is the most significant fault of the study area (Figs. 4-6). On the same fault, there is a second striation orientation $\left(125^{\circ} / 80^{\circ} / 85^{\circ}\right.$ - left reverse) that indicates multiphase movement on the CSB Fault.

The other major fault zone is the Bear Fault Zone with normal faults (BF in Fig. 6), which is located in the north of the structure. The movement on this fault is estimated at more than $100 \mathrm{~m}$ (based on depths of bauxite and hanging-wall deposits in boreholes) (Figs. 4-6). The layers are horizontal to slightly inclined $\left(\sim 10^{\circ}\right)$, which indicates that the structure between these faults is not significantly tectonically disturbed (Figs. 4 and 6).

\section{MATERIALS AND METHODS}

The construction of a 3D geological model consists of a series of actions. The first stage of this process includes: collection and systematization and integration of data, field mapping of underground mining objects (adits and tunnels), digitization and georeferencing of input data and placing them into 3D geodatabase. The second stage consists of the construction of geological cross-sections, reconstruction of fault surfaces, palaeorelief and bauxite surfaces, reinterpretation of borehole data and the development of bauxite solid models (individual bauxite bodies; Fig. 7). The final stage was trimming parts of the surfaces outside the research area, smoothing the surfaces, and calculating the dimensions and volume of the bauxite deposits.

\section{INPUT DATA AND PROCESSING}

The input data are different according to type, resolution, density and quality. The data can be sorted as surface vs. underground and geological vs. non-geological data. Surface geological data include existing geological maps of the study area (scale 1:25,000, and scale 1:1000 for individual bauxite deposits), while underground data include those collected by the geological mapping of underground mining objects, borehole data, and previously published geological sections (Figs. 7 and 8). Non-geological data are topographic maps (scale $1: 25,000$ and 1:1000), digital elevation model, maps of adits and tunnels, and orthophoto images.

All input data were first imported into a GIS database. Old, handwritten geological maps (Dragičević, 1981; Papeš, 1984, scale 1:25,000) and maps of adits and tunnels (scale 1:1000) were georeferenced and digitalized. Furthermore, the digital elevation model (DEM) of the terrain is derived from topographic maps (scale 1:1000) developed by the Rudnici boksita Jajce company. One of them is used as the topographic base of the detailed geological map (Fig. 6) of the study area. This DEM was the basis for assigning elevations for surface geological data (measured structural elements, geological boundaries, faults, borehole heads; Fig. 8D). The geological maps (Dragičević, 1981; Papeš, 1984; scale 1:25,000; Fig. 6) were digitized and updated with new measurements in ArcGIS. Faults, geological boundaries and measured structural elements were digitized and prepared for importing into Midland Valley Move software (http://www.mve.com/) and then placed into a 3D environment (Fig. 8). Approximately $10 \mathrm{~km}$ of underground mining tunnels and adits were not previously geologically mapped (Fig. $8 \mathrm{~A}, \mathrm{~B})$. Consequently, through this research, geological mapping of the accessible underground mining objects was conducted to gain a better interpretation of faults and boundaries between the footwall and hanging-wall strata to bauxite deposits (i.e. palaeorelief surface; Fig. 8).

Borehole data, i.e. lithological columns from cores of 600 boreholes drilled over the last 40 years, represent the most important group of input data (Table 1; Fig. 8B-D). The following borehole horizons were defined and digitized:

- top of bauxite deposits footwall,

- top of bauxite deposits.

It is difficult to express the quality of input data numerically. Non-geological data (topographic maps, maps of adits and tunnels, DEM) are very good because the area has a dense geodetic control network. The quality of geological data was not easy to assess. Maps and cross-sections were made based on surface mapping and few structural wells (Dragičević, 1981; Papeš, 1984) and digitally updated with newer data (geological map in Fig. 4). Based on these maps and cross-sections (Fig. 4), there has been a lot of success in finding bauxites, so the maps are also a solid base for further research. The most questionable input data are borehole inter- 


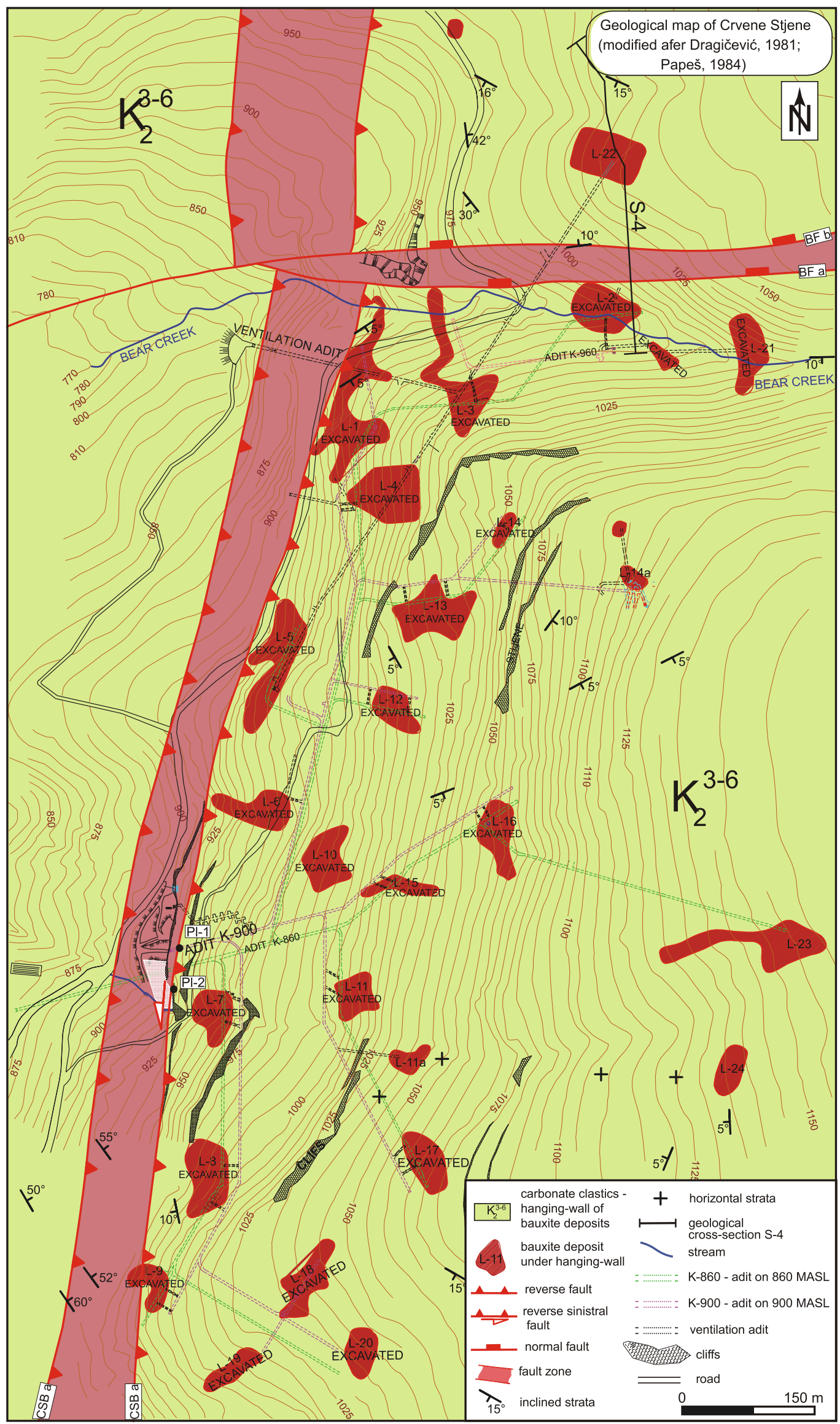

Fig. 6. Detailed geological map of Crvene Stijene (modified after Dragičević, 1981; Papeš, 1984) 


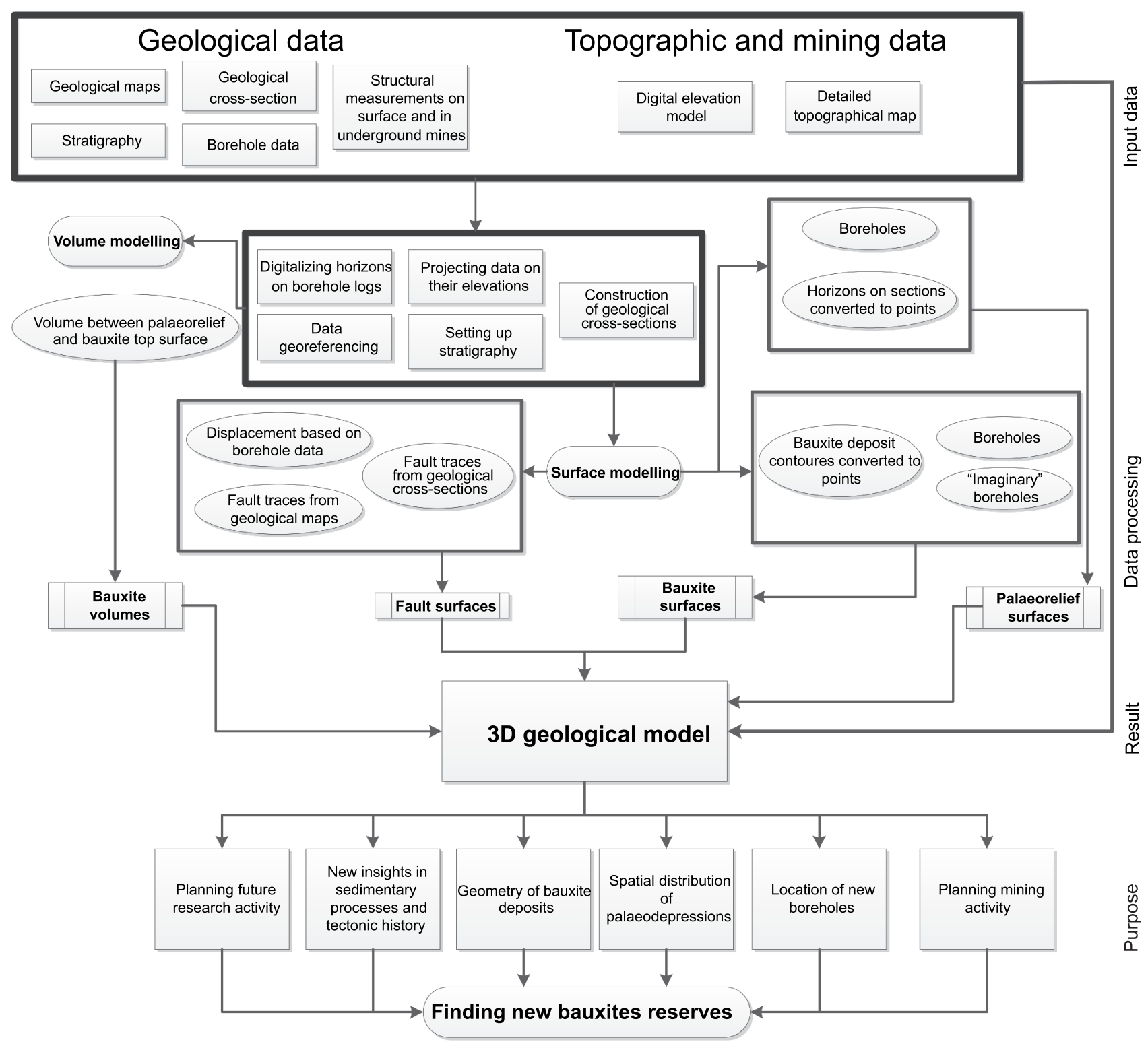

Fig. 7. Workflow of the modelling approach

pretations. It mostly depends on the knowledge of the geologists who interpreted the drill cores. Boreholes that drilled bauxites are foreshore reliable input data in sense of depth to bauxites and palaeorelief. Lithologically, the hanging-wall and footwall to bauxites are very different. The hanging-wall is represented by carbonate clastics (breccia, conglobreccia, calcarenites and marls) and the footwall is composed of shallow-marine limestones. However, it is not always easy to determine the boundary between footwall and hanging-wall rocks. Breccias can contain large clasts, over a metre in size (see Fig. 3A). The clasts originate from footwall limestones and can deceive the interpreter that the borehole was drilled in the footwall. In that case, the depth to the palaeorelief can be underestimated. Also, footwall limestones directly beneath the boundary can be highly karstified (looks very similar to the hanging-wall breccia). In that case, the depth to the boundary can then be overestimated. Based on the palaeorelief surface geometry (depth anomalies are the result of false input data incorrect depth to the surface) in a 3D geological model, borehole data will be revised and reinterpreted.

\section{METHODS USED}

\section{MODEL CONCEPTUALIZATION AND BUILDING}

The modelling process started with the construction of 46 geological sections perpendicular to the structure, and 3 geological sections longitudinal to the structure. Then, fault surfaces, palaeorelief and top of bauxite surfaces were constructed. That part was most challenging and time-consuming.

Each of the surfaces was of different type and complexity (fault surfaces, palaeorelief surfaces - basal and top surfaces of bauxite deposits). They are also defined by a different type, quantity and quality of input data (Table 2). For each surface type, it was necessary to use a different interpolation algorithm (Table 2). Faults were mostly defined by intersections and measurements in the adits, while movements on faults are interpreted based on different depths of horizons in boreholes on both sides of the faults (Fig. 9). 

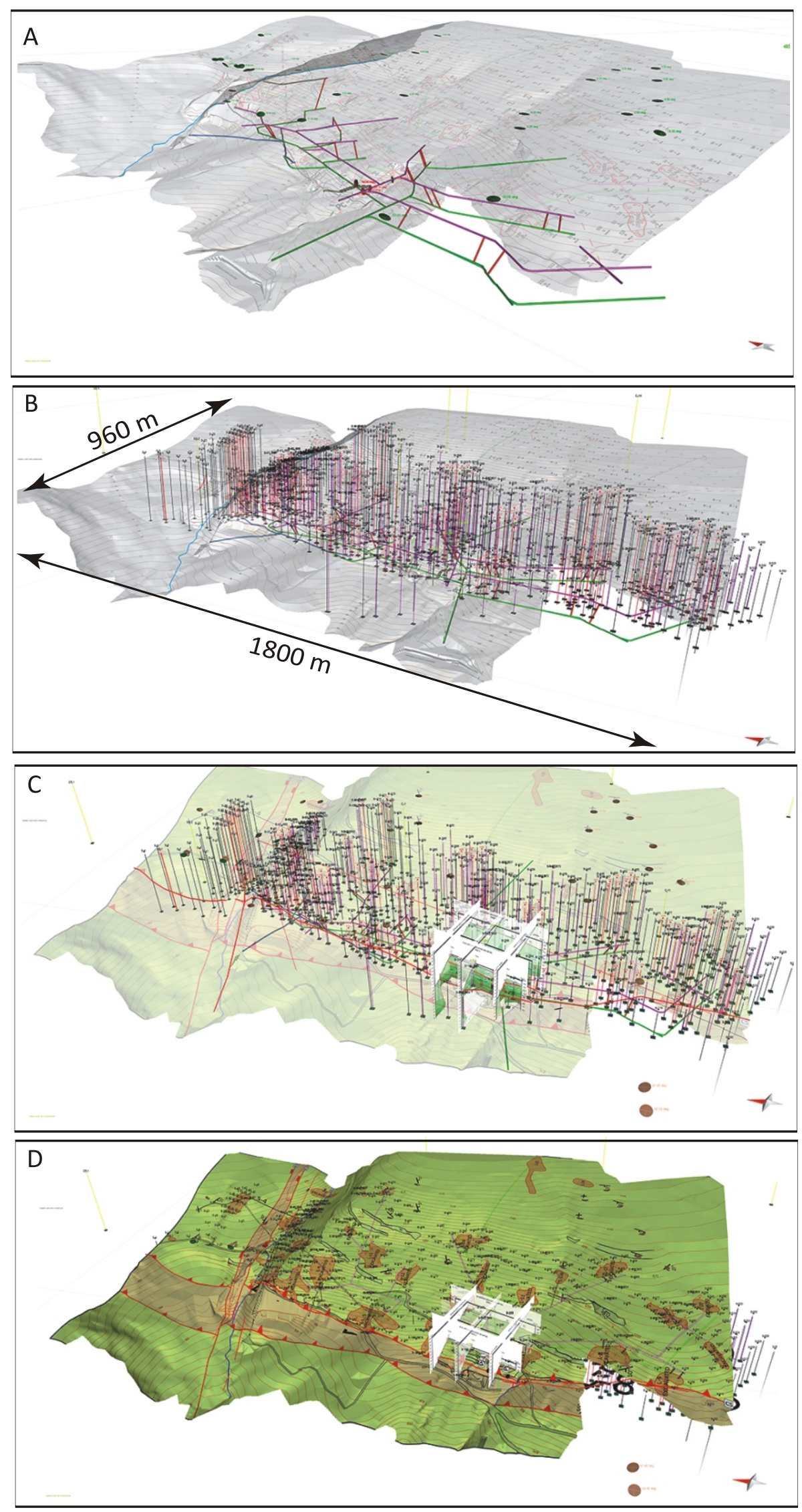

Fig. 8. 3D view of input data

A - DEM with bedding measurements and adits; $\mathbf{B}$ - DEM, adits and boreholes; $\mathbf{C}$ - transparent DEM with draped geological map (see Fig. 6), adits, boreholes and geological cross-sections; D DEM with draped geological map (see Fig. 6 geological cross-sections, and bedding measurements) 
In terms of geometry, palaeorelief surfaces are the most complex. In this model, palaeorelief is represented with several surfaces confined by faults and the boundary of the study area. These surfaces require large amount of input data. Therefore, they were built based on 600 boreholes and geological sections in the areas where there are few or no boreholes.

Top surfaces of the bauxite deposits have relatively small areas and irregular shape in comparison to palaeorelief and fault surfaces. These surfaces are modelled based on two types of input data:

- boreholes which have penetrated the bauxite deposits and imaginary boreholes created for the better fitting of shape of bauxite top surfaces;

- boundaries of bauxite deposits from detailed topographic maps (visible in Fig. 6), which are digitized and projected onto palaeorelief surfaces.

To obtain the shape, size and volume (in $\mathrm{m}^{3}$ ) of bauxite deposits, solid models were created between palaeorelief surfaces and the bauxite top surfaces. These solid models show the shape of the deposits, therefore the dimensions and volume (in $\mathrm{m}^{3}$ ) of individual deposits could be easily calculated.

Fault modelling. The faults were modelled based on surface fault traces from geological maps (Fig. 6), measurement of structural elements in the adits and on the surface, and boreholes from both sides of the fault planes (for example, Fig. 9). Three fault planes were constructed:

- the Crvene Stijene-Bešpelj Fault (Fig. 6), striking nearly $\mathrm{N}-\mathrm{S}$, is the most important fault of the study area, and it represents the western boundary of the Crvene Stijene structure. The fault plane was created using the Extrusion algorithm. The Extrusion tool can be used to create a surface from a single line (surface trace or line on a geological cross-section), and a fault mesh from a single fault stick. Input data for this algorithm are the surface trace of the fault, dip angle, curvature of the plane, and depth of the projection. Strike, dip and rake were measured on the surface and in the adits (Figs. 5 and 6): $125 \% 80 \%$ with rake $10^{\circ}$ - left reverse. According to data from the geological cross-sections based on boreholes from both sides of the fault, the estimated maximum throw of the CSB fault in this area is $\sim 140 \mathrm{~m}$;

- the Bear faults, i.e. fault zone consists of two main normal faults, BF a and BF b (Figs. 6, 8 and 9). The faults planes were built based on six geological cross-sections and data from boreholes from both sides of the fault zone (Fig. 9). Data were interpolated with linear interpolation algorithm. This algorithm has proven to be satisfactory for the surfaces of simple morphology and geometry that do not have sudden changes in strike and dip. The maximum throw on the Bear Fault Zone exceeded $180 \mathrm{~m}$.

Surface horizon modelling. The first step in surface horizon modelling was defining the stratigraphic column and choosing the horizons. For the purpose of this research, two horizons were defined (Fig. 9) on the detailed stratigraphic column (Fig. 4).

- palaeorelief surface - footwall surface of bauxite deposits; - top surface of bauxite deposits.

Palaeorelief surface modelling. Karst bauxites were formed during the terrestrial phases, i.e. emersions. One of the requirements for the formation of bauxites is the diverse palaeorelief surface, on which they were formed. Negative anomalies in the relief, such as depressions, sinkholes, karst valleys and canyons, are the result of pre-bauxite tectonics, erosion and the karstification of carbonate rocks. These pro-

Table 1

Boreholes used in the 3D geological modelling process

\begin{tabular}{|l|c|}
\hline \multicolumn{1}{|c|}{ Borehole type } & Number of used boreholes \\
\hline Structural boreholes & 13 \\
\hline Boreholes drilled for dimension stone & 5 (drilled in 2015) \\
\hline Positive boreholes on bauxite & 171 \\
\hline Negative boreholes on bauxite & 411 \\
\hline
\end{tabular}

Geological objects, input data, and interpolation algorithms used in modelling workflow

\begin{tabular}{|l|c|c|}
\hline \multicolumn{1}{|c|}{ Geological object } & Input Data type & Interpolation algorithm \\
\hline PS between CSB Fault and BF & $\begin{array}{c}\text { borehole markers and PS lines on geological } \\
\text { cross-sections converted to point sets - point data }\end{array}$ & Ordinary Kriging \\
\hline PS north of BF & $\begin{array}{r}\text { PS lines on geological cross-sections - line data; } \\
\text { borehole markers - point data }\end{array}$ & Inverse Distance Weight (IDW) \\
\hline PS west of CSB Fault & PS lines on geological cross-sections - line data & linear interpolation \\
\hline PS between BF & PS lines on geological cross-sections - line data & linear interpolation \\
\hline CSB Fault & fault line on geological map - line data & Extrusion \\
\hline Bear faults & fault lines on geological cross-sections - line data \\
\hline Bauxite deposits top surfaces & $\begin{array}{c}\text { boreholes, imaginary boreholes and bauxite de- } \\
\text { posit contours converted to point sets - point data }\end{array}$ & Delaunay triangulation \\
\hline Bauxite deposit volumes & $\begin{array}{c}\text { palaeorelief surfaces and top of bauxite deposit } \\
\text { surfaces - surface data }\end{array}$ & TetraVolume Between Horizons \\
\hline \multicolumn{2}{|c|}{${ }^{*}$ PS - palaeorelief surface; BF - Bear faults; CSB - Crvene Stijene-Bešpelj Fault } \\
\hline
\end{tabular}


Geological cross-section S-4

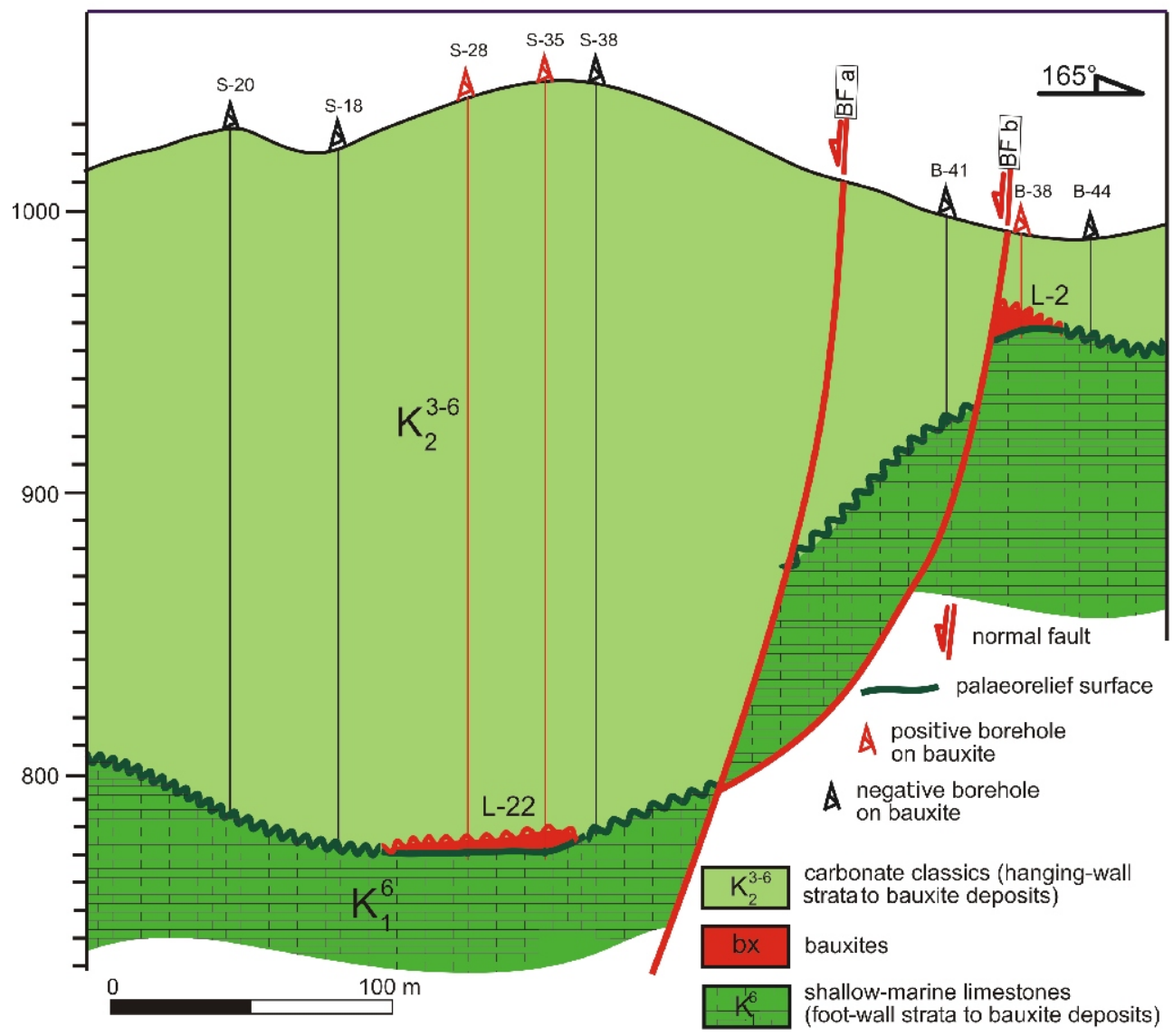

Fig. 9. Geological cross-section perpendicular to the Bear faults

cesses result in a relatively complex geometry of palaeorelief surface (footwall of bauxite deposits). The surface geometry can then become even more complex with subsequent tectonic activity (faulting and folding).

For the construction of a reliable model of such surfaces, it is necessary to have a large amount of input data (especially boreholes) and complex interpolation algorithms.

Palaeorelief consists of four surfaces, whose boundaries are represented by the Crvene Stijene-Bešpelj and Bear faults (Fig. 6) and the study area boundary. Each palaeorelief surface in the model is defined by a different type, density and quality of data. Therefore, different data processing and interpolation algorithms were necessary for each surface.

For the interpolation of the surface between the Crvene Stijene-Bešpelj and Bear faults, the following data were used: palaeorelief horizons from 554 boreholes, and palaeorelief lines on geological sections, which were transformed into a series of point data sets. Only interpolation algorithm, within the Move software, that gives realistic output for this amount and quality of input data, was Ordinary Kriging (Figs. 10 and 11). Variograms were calculated automatically based on spatial distribution of input data; grid geometry and anisotropy (Fig. 10). Dimensions of cells within the interpolation grid were set to $2 \times$ $2 \mathrm{~m}$, that gives high resolution of the created model with respect to the size of the study area. To obtain as much input data as possible, 46 geological cross-sections, with interpreted palaeorelief horizons, were created. Those interpretation lines were transformed into point datasets (Fig. 11A) and used with borehole horizons as input data for the surface interpolation. Interpretations from sections contributed the most in the marginal area and in the areas where boreholes were absent. The results obtained from other interpolation algorithms were not satisfactory, primarily due to the complex morphology of the surface (Fig. 11).

The BF Zone consists of two normal faults, BF a and BF b. Based on borehole data from both the hanging-wall and the footwall of the BF Zone, six geological sections were made to define the palaeorelief surface between BF $a$, and BF $b$ (Fig. 12). This surface is constructed by line interpolation, with linear interpolation algorithm, the same way as the BF were made. After line interpolation, the created surface was cropped by BF a and $\mathrm{BF} b$ fault planes to fit space between the faults. A relatively small amount of input data and simple surface geometry make the results of this interpolation satisfactory.

There are 46 boreholes in the area north of the Bear faults. The relatively small number of boreholes and their irregular spatial distribution make results of any interpolation algorithm unsatisfactory. Therefore, 13 geological sections were created between the boreholes, in which the palaeorelief surface was interpreted (e.g., Figs. 9 and 12). Palaeorelief interpretation lines (line data) on cross-sections, along with borehole markers (point data), were used for the construction of the surface with Inverse Distance Weight algorithm. Grid geometry parameters were set to cell dimensions of $5 \times 5 \mathrm{~m}$. The reason for the larger 


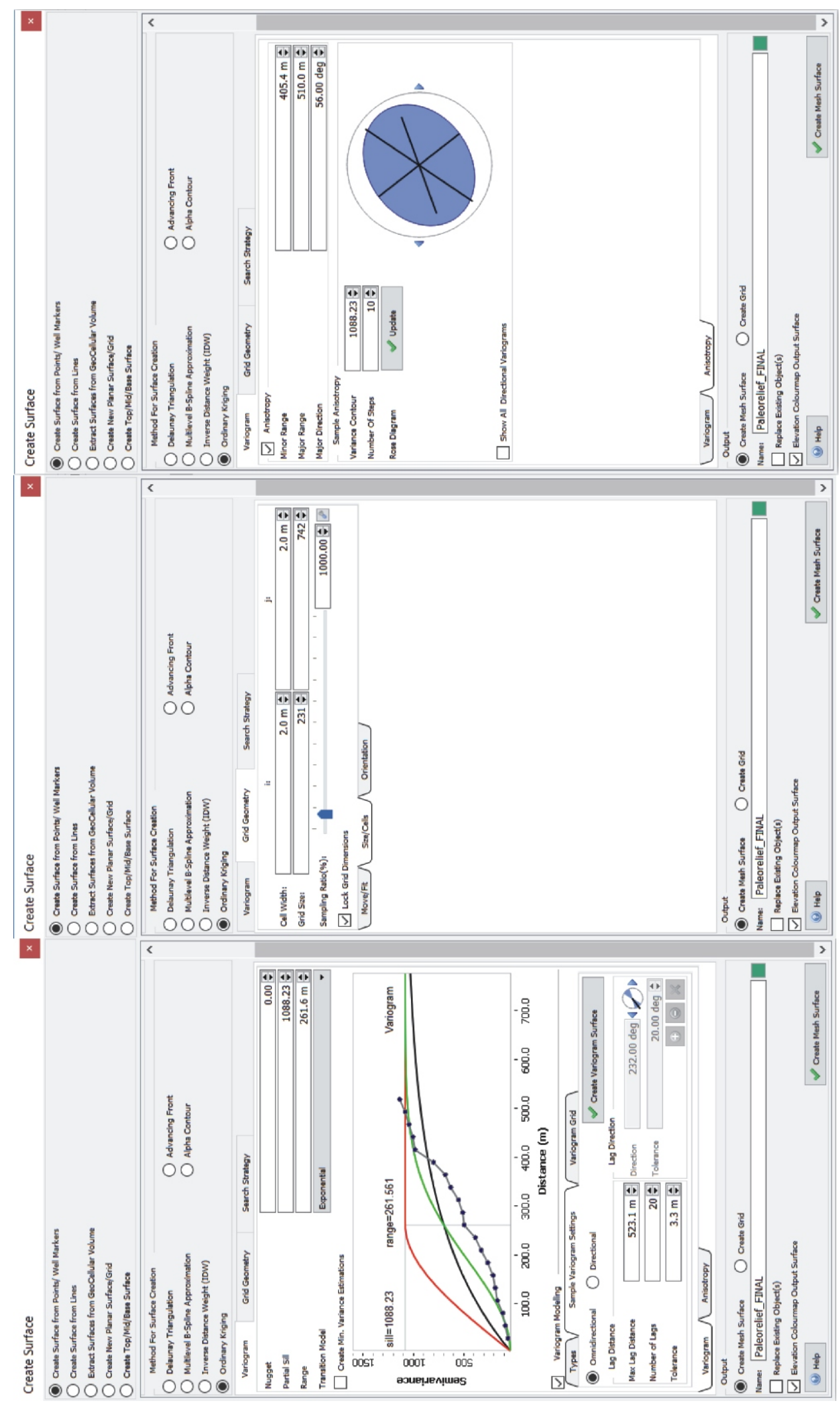

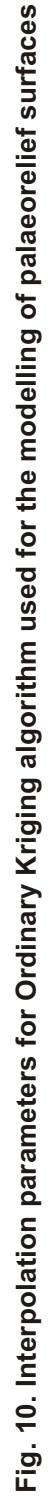




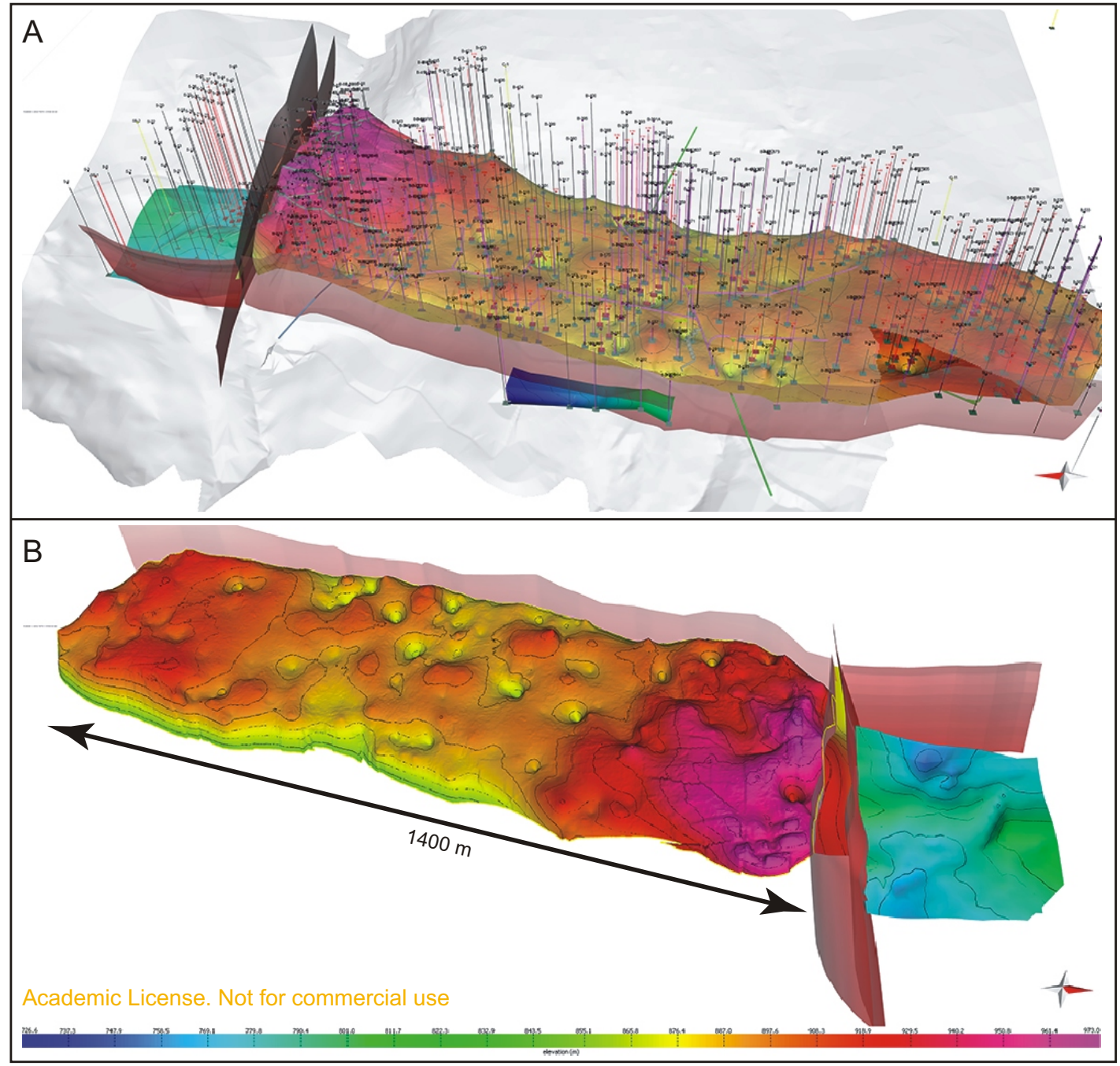

Fig. 11. Palaeorelief surfaces with main faults; DEM was turned off on image $B$ for better visibility of palaeorelief surface

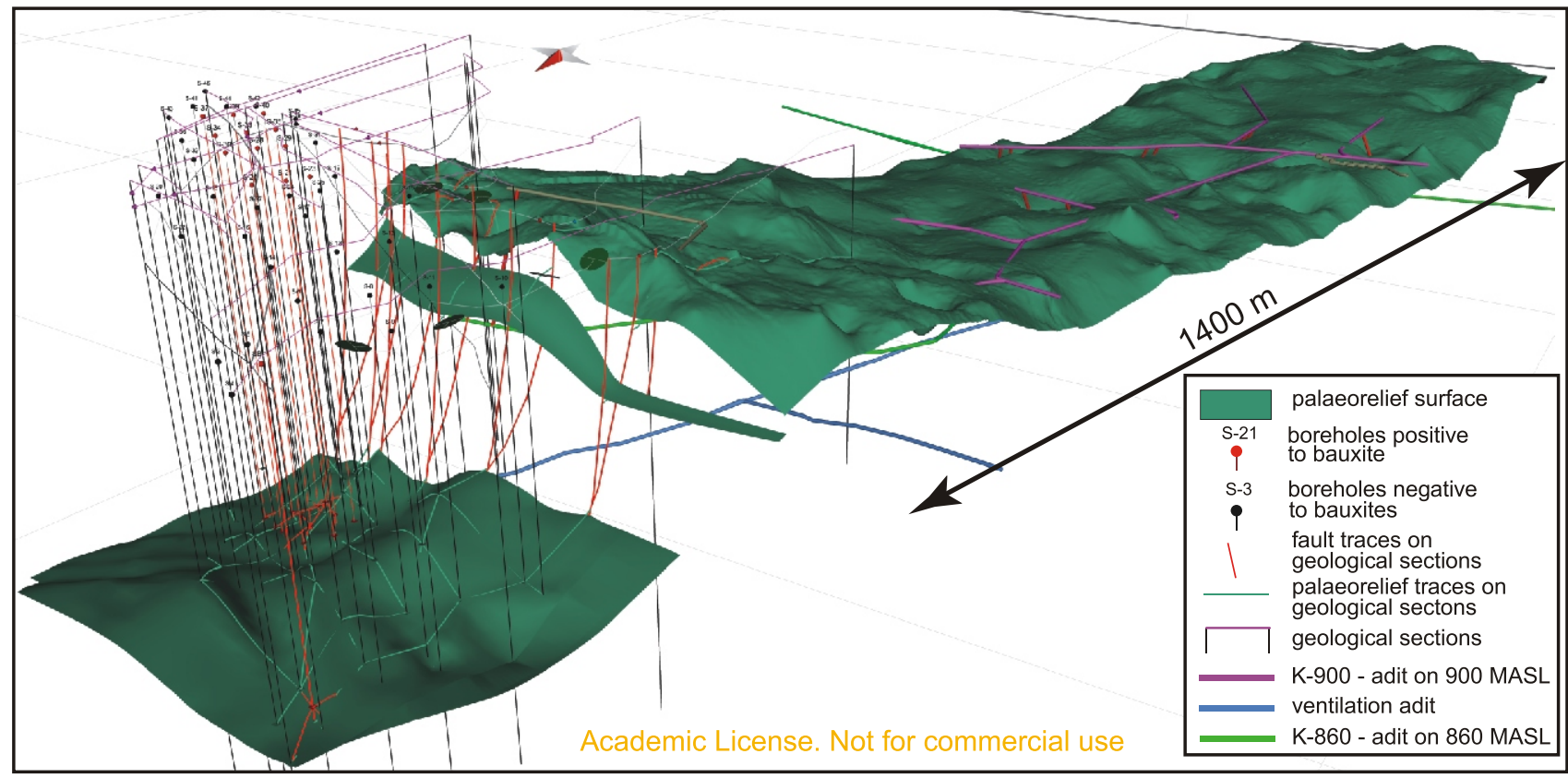

Fig. 12. Palaeorelief surface north of the Bear Fault Zone with corresponding input data (boreholes and geological sections) 
cells for this surface was a smaller spatial density of input data (Figs. 11 and 12). Surface morphology is relatively simple without large and sudden changes in depth. Similar results were obtained by Ordinary Kriging algorithm. The only difference in interpolation process was that prior to interpolation it was necessary to convert palaeorelief interpretation lines from geological sections into point data sets, and then apply Ordinary Kriging algorithm.

For the palaeorelief surface eastern from the CSB Fault there were only six boreholes. Still, the surface was constructed, mostly for assessing the movement on CSB Fault. Perpendicular to the CSB Fault, through these boreholes, geological cross-sections were created. These were the basis for the linear interpolation of line data with linear interpolation algorithm. Angle of this surface (visible in the colour changes in Fig. $11 \mathrm{~A})$ corresponds to the structural measurements along the
CSB Fault (PI-1 and $\mathrm{Pl}-2$ in Fig. 6). Maximum vertical movement on CSB Fault in the research area, based on this small amount of data, was estimated on $140 \mathrm{~m}$.

Top surface of bauxite deposits modelling. Top surfaces of bauxite deposits were almost impossible to model based on the available input data. A relatively small number of boreholes that penetrate bauxite deposits were not enough for the satisfactory modelling of geometry of the top surface of bauxites (Figs. 13A and 14A). Therefore, it was necessary to collect more input data. Contours of bauxite deposits from detailed topographic maps (in the background of geological map in Fig. 6) were used as additional input data. Contours were digitalized, projected onto palaeorelief surfaces and converted into point datasets (Fig. 13B). Still, the results of interpolation, with any algorithm, were unsatisfactory for bauxites with complex geometry. The main reason for this was a small number of bore-

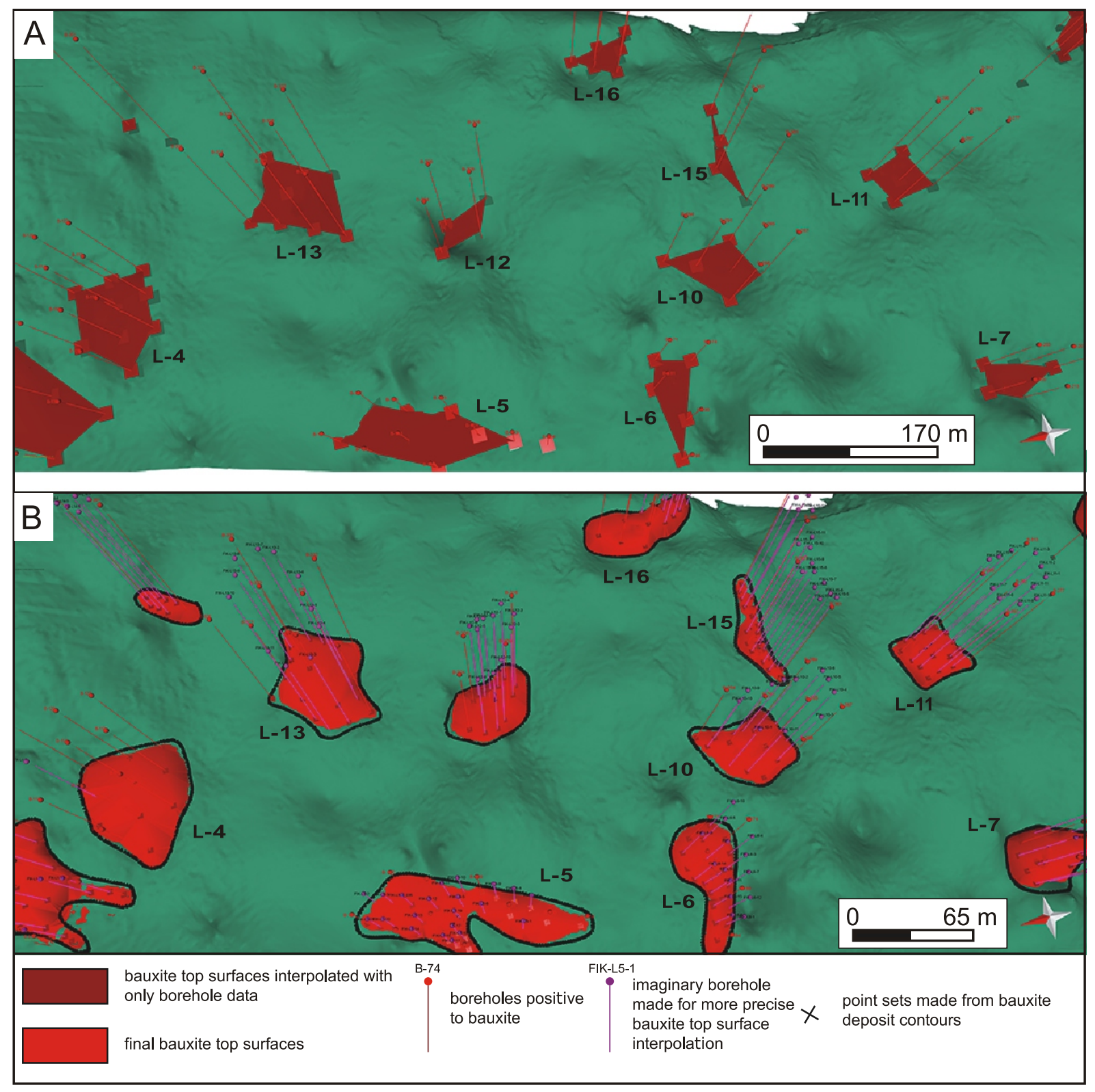

Fig. 13. Example of interpolation results before and after expanding of the input data set

A - interpolation based only on borehole data; B - interpolation based on borehole, imaginary borehole and contour data 


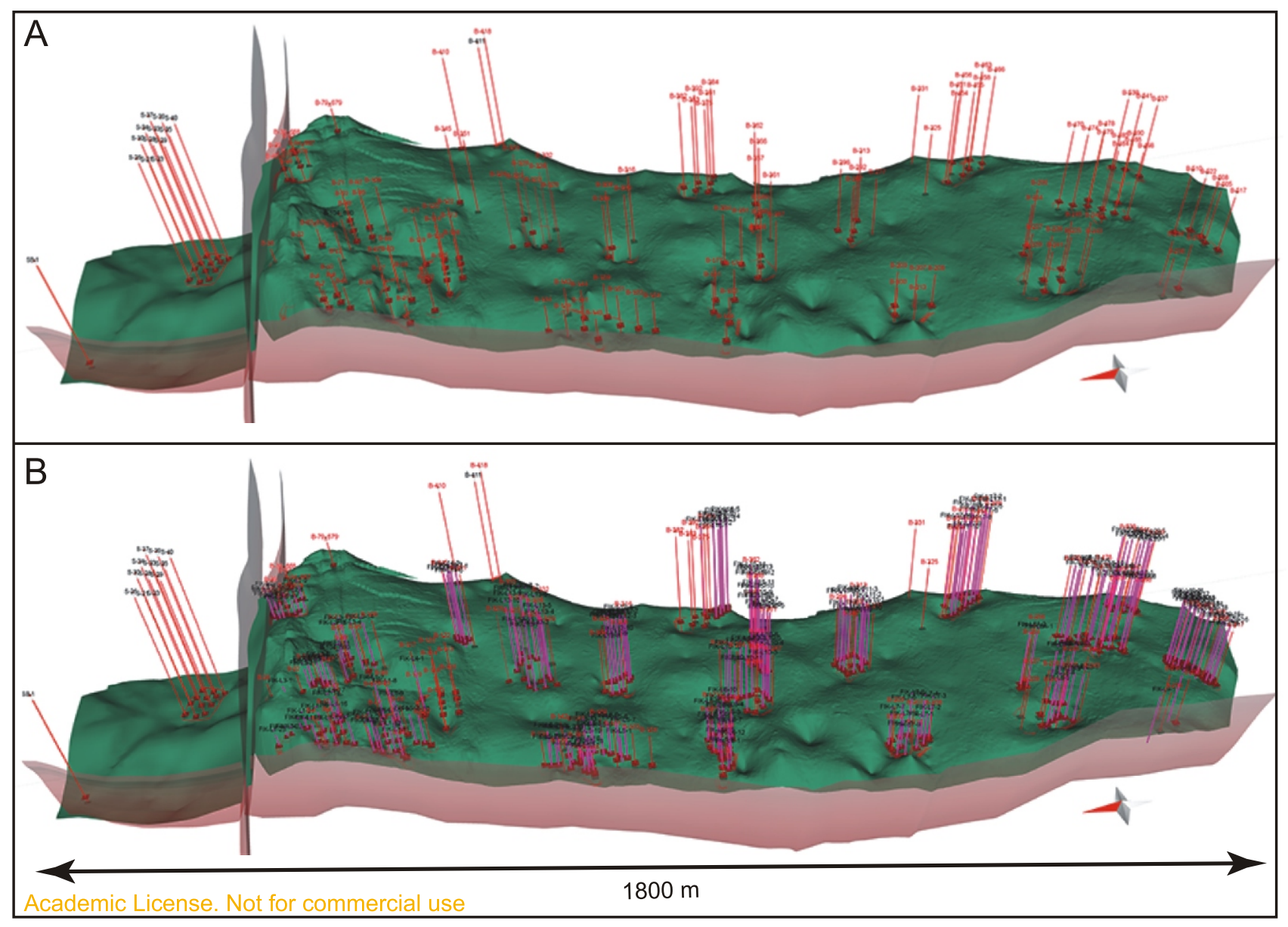

Fig. 14A - palaeorelief surface with positive boreholes on bauxite;

B - palaeorelief surface with all positive boreholes on bauxite, and imaginary boreholes

holes with too much space between them, or too much distance from the boundary contour (Fig. 13A). As a result, imaginary boreholes were made, for each deposit on which the depth to the bauxite was determined by arithmetic mean between the two closest boreholes (Figs. 13B and 14B). For all the deposits, a total of 240 imaginary boreholes were made (Fig. 14B). Surfaces were then modelled with the Delaunay Triangulation interpolation algorithm and they were further processed with the Smooth algorithm, to smooth out the edges and peaks. The results were surfaces, which correspond to the geometry, and boundaries of bauxites (Figs. 13B and 15). The top surfaces of bauxites were trimmed by palaeorelief surface using the split tool, so their boundaries perfectly fit on the palaeorelief surface (Figs. 13B and 15).

Bauxite solid models. Last phase of the modelling process was building solid models of each individual bauxite deposits. The solids were made individually for each deposit using the Volume $\rightarrow$ Create TetraVolume Between Horizons tool. It is only necessary to define the bottom and top surface, the length of cell sides (the smallest possible was chosen: $5 \mathrm{~m}$ ) and the name of the solid model.
The procedure was repeated for each deposit (Figs. 7, 16 and 17). Once the solid models of bauxites were built, we had direct insight into the bauxite deposits shape, type, size and volume (software calculates it automatically).

\section{RESULTS}

Geological modelling in three dimensions requires large amount of input data. Therefore, models can be very useful in solving scientific and engineering problems but challenging to build. The applied methodology includes integration, digitalization, systematization and visualization of different types of data (600 boreholes, geological maps and cross-sections, DEM, structural measurements from the surface and in the tunnels and adits) in 3D geodatabase. In the modelling workflow, different types of geological objects were modelled with different interpolation algorithms. The interpolation algorithm used in the modelling depends on the complexity and geometry of geological object, as well as the type, quantity and quality of input data. 


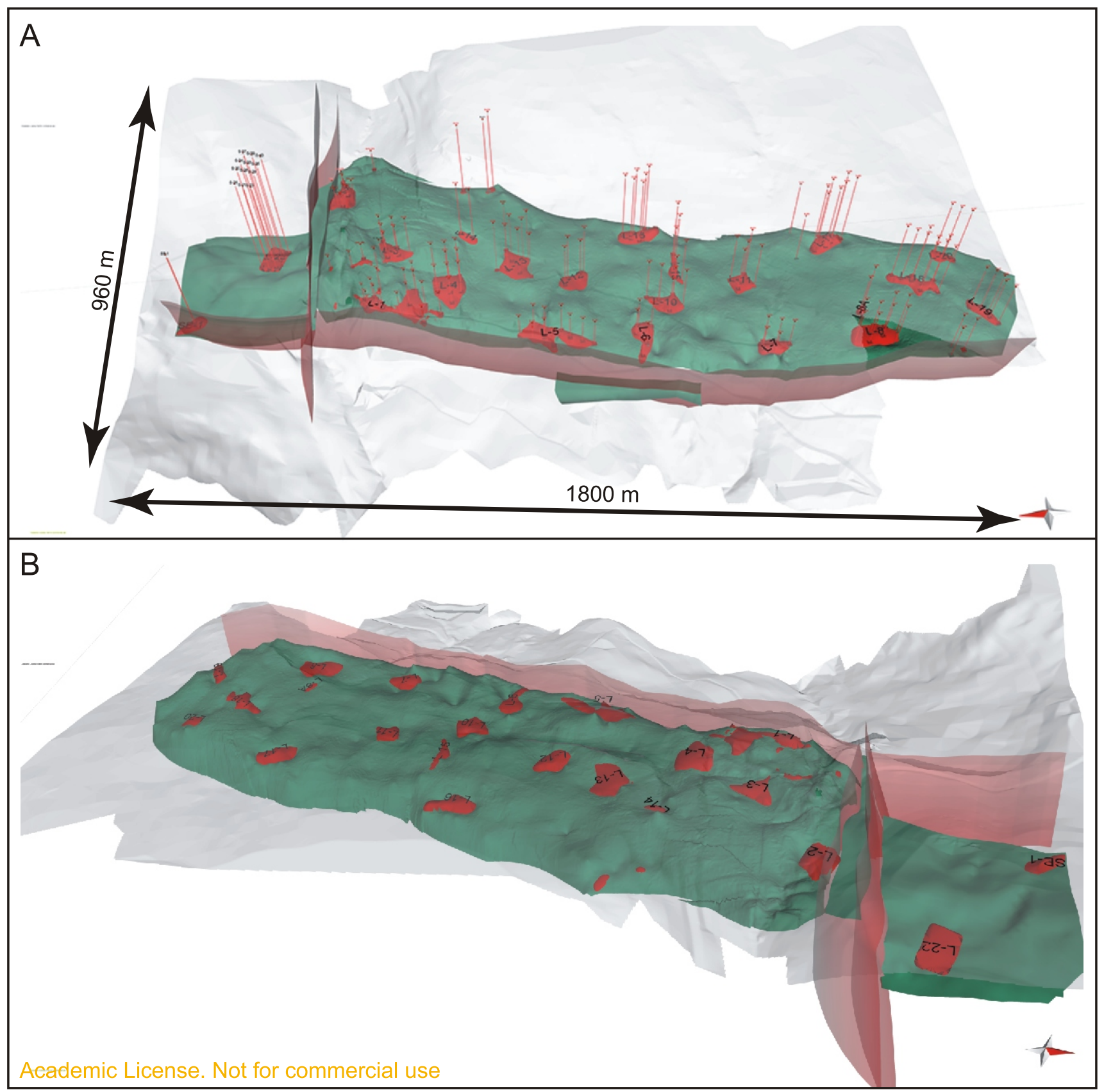

Fig. 15. 3D model of palaeorelief and bauxite deposits in the Crvene Stijene area

For example, palaeorelief surfaces (footwall surfaces to bauxites) are covered with data from boreholes (point data), geological sections (line data) and a combination of both. Borehole quality was assessed based on palaeorelief surface geometry. Anomalies of the surface depth can be the result of an over/under-estimation of depth in the borehole, especially if the anomaly is not present in neighbouring boreholes. These boreholes are then reinterpreted.

The palaeorelief surface between the CSB and BF has the most complex morphology, and it is covered with the greatest number of input data, so it was interpolated with Ordinary Kriging. North of the Bear Faults, there were insufficient borehole data, and the boreholes are irregularly distributed. For this reason, it was necessary to create a mesh of geological cross-sections between the boreholes, and then use the IDW algorithm. The similar result was achieved with the Ordinary Kriging, however, further optimization was required after interpolation. The surfaces and fault planes with the smallest amount of input data (BF a and $b$, palaeorelief in the Bear Fault Zone between BF $a$ and BF $b$ and palaeorelief west of the CSB Fault) are interpolated based on constructed geological cross-sections using the linear interpolation algorithm. The CSB Fault is defined by structural measurements on the surface and in the adits, and with the fault trace on the surface (visible in Fig. 6). The fault plane was created using the Extrusion algorithm, which builds a plane from the fault trace into the depth at a defined angle. The top surface of bauxite de- 


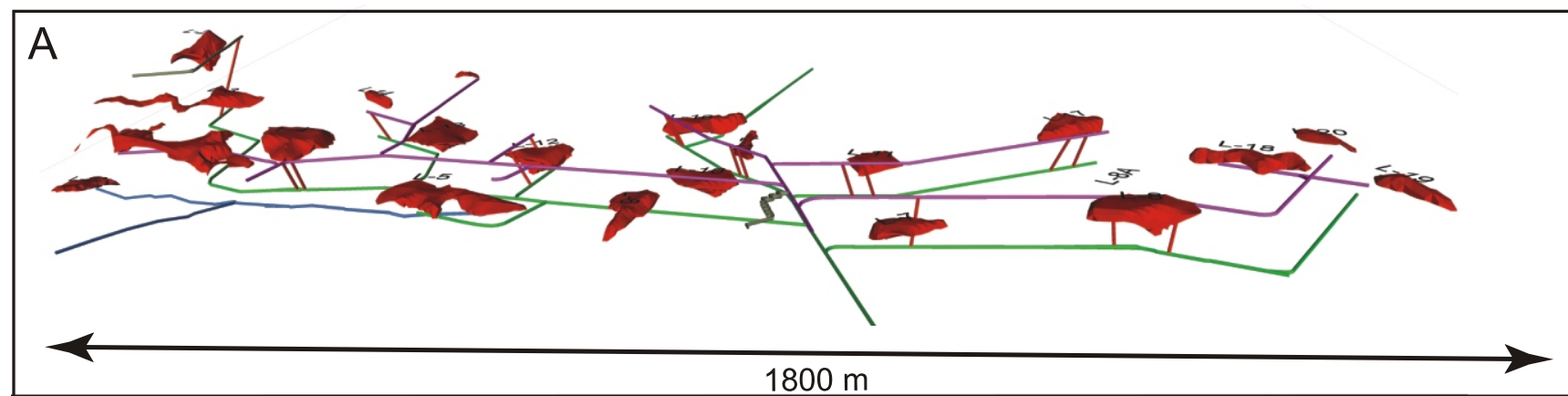

\section{B}

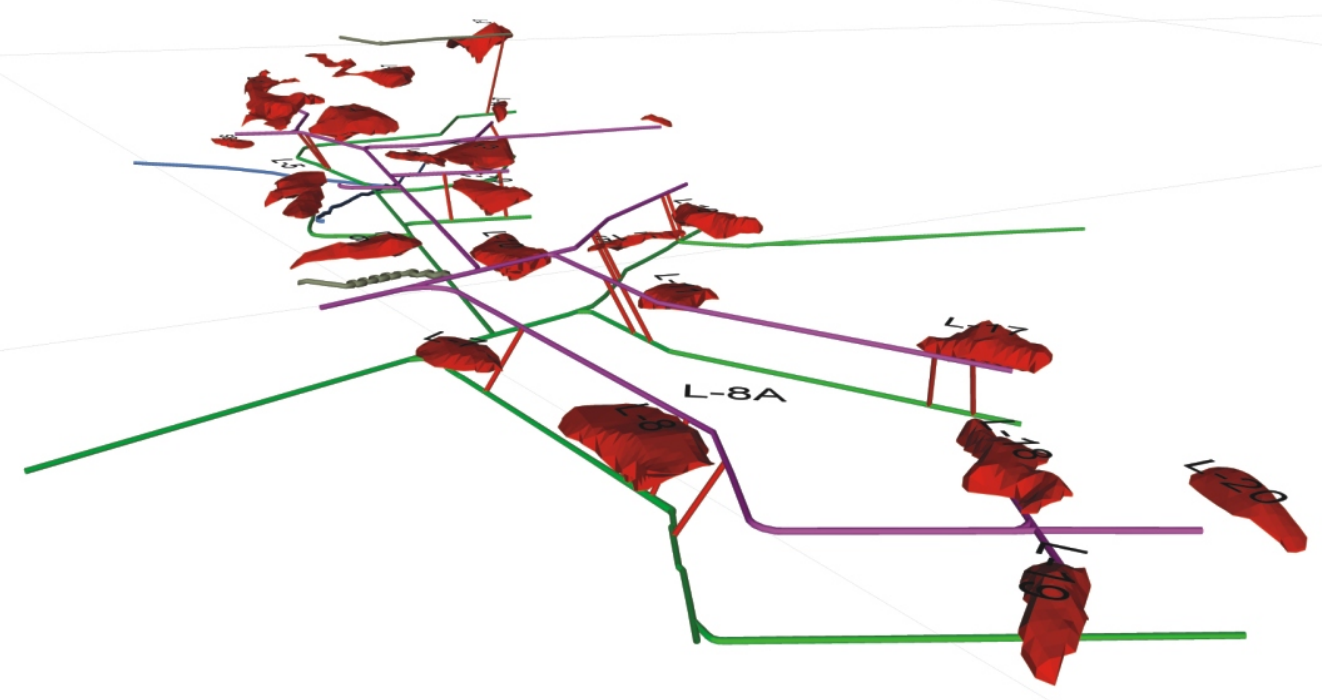

Academic License. Not for commercial use

Fig. 16. Solid models of bauxites with adits and tunnels

posit required the most preliminary work, i.e. expanding the input data set with imaginary boreholes (Fig. 13) and bauxite deposit boundary contours. Due to the irregular boundaries and small dimensions, Ordinary Kriging and IDW did not give satisfying results (Fig. 13). The best results for bauxite top surfaces were achieved with the Delaunay Triangulation algorithm and gentle smoothing of the interpolated surface.

Once the footwall and hanging-wall surfaces were constructed, bauxite solid models were simple to build. With the Volume tool and the TetraVolume Between Horizons algorithm, the solid model was built for each individual deposit. With the constructed model, it is easy to visualize depressions in the palaeorelief surface, which are the precondition for bauxite deposits formation. In addition, the spatial distribution of bauxite deposits, their morphology and geometry, size and shape, can all be visualized in the 3D model.

In the study area, there are six types of bauxite deposits: lenticular, canyon-like, graben type, sinkhole type, canyon like with a sinkhole at the end, and tectonized (bauxite types according to Bárdossy, 1982; Appendix 1* and Fig. 18). Deposits L-1 and L-5 are relatively close to the CSB Fault, which obvi- ously had impact on their current elongated geometry (Fig. 18). Deposit L-2 is situated along the Bear faults and its geometry could also be influenced by the fault. Despite that, its geometry is characterized as lenticular or graben type (Fig. 9). The most common bauxites are of sinkhole type. Their geometry depends mainly on the geometry of the palaeorelief, i.e. the shape of the depression in which the bauxites were deposited (Figs. 11 and 18). Furthermore, few deposits (L-14, L-15, L-18 and L-19; Fig. 18) are "canyon-like" deposits. Their geometry and thickness indicate that they are formed in palaeo-canyons. The thicknesses indicate that the canyon height could exceed $15 \mathrm{~m}$. Furthermore, L-3 and L-6 also have a "canyon-like" geometry with a sinkhole at the end (Fig. 18). These geometries indicate that the sedimentation mechanism for these bauxites derives mainly from water streams. There are a few bauxite deposits that were too small for solid model construction (L-8a, 410 and 411/18). These deposits are classified as bauxite "nests" or "bags".

In Appendix 1 there are volumes calculated based on a 3D model and from the study on reserves for each individual deposit. In the study on reserves, the volumes were calculated by 


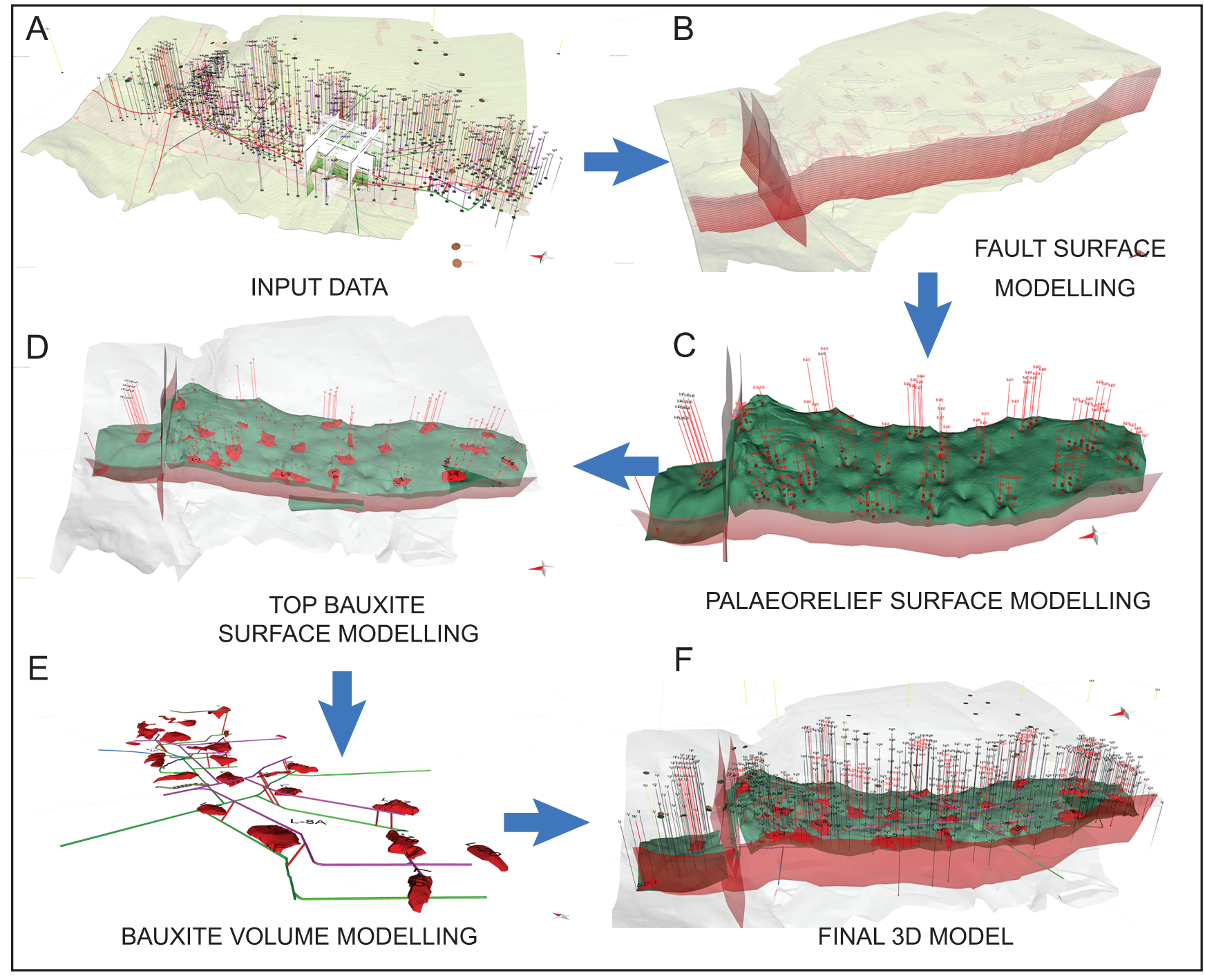

Fig. 17. Modelling workflow for the 3D model of the bauxite bearing-area Crvene Stijene

the method of parallel vertical sections. For most of the deposits, the volumes from the 3D geological model are slightly higher as compared to those from the study on reserves. That can be explained in such a way that the $3 \mathrm{D}$ model has a higher resolution than the parallel vertical section method. It is hard to quantify which method is better, but for mining purposes, both give a satisfactory result.

\section{CONCLUSIONS}

The paper presents the applied workflow for constructing a reliable high-resolution 3D geological model based on variety of input data. The workflow can be applied in solving scientific problems of palaeogeographic reconstruction of bauxite deposits based on their geometry and geometry of palaeorelief surface, and interpretation of sedimentological and structural evolution of the area. Input data, like borehole logs, geological maps and cross-sections, can be optimized and reinterpreted with respect to spatial geometry of geological bodies in the model. Therefore, input data can be reassessed and improved, especially the borehole logs. The model also represents the basis for planning ongoing research and mining activity. Based on this model, development of new adits and tunnels can be planned with respect to faults, fault zones and rock types in the hanging-wall and footwall to bauxite deposits. Therefore, the location and length of the roof support can be estimated, as any other geology-related difficulties during mining. Furthermore, newly found deposits could be quickly characterized by contouring which assures easier volume calculation of deposits. The constructed model is easily upgradable with new data. This is important because there are constantly ongoing research activities: planning, locating and drilling boreholes, constructing the underground mining objects, etc., which can be easily imported into the model.

The next phase in the modelling workflow would be the development of a 3D geological model of two neighbouring bauxite-bearing areas, Bešpelj and Poljane. Modelled area of this size would be suited for more regional palaeogeoraphic and tectonic interpretation of the area. 
L-1

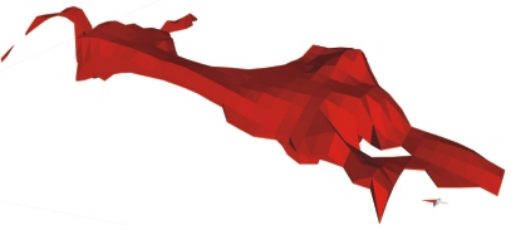

L-4

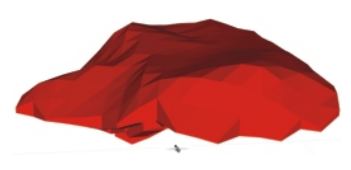

L-7

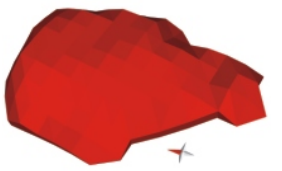

L-11

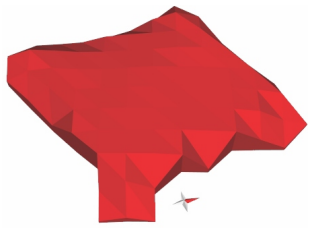

L-14

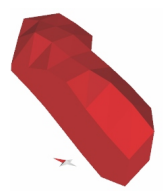

$\mathrm{L}-17$

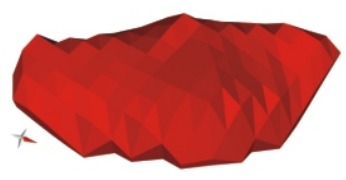

L-20

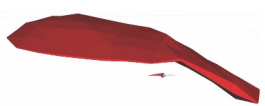

L-2

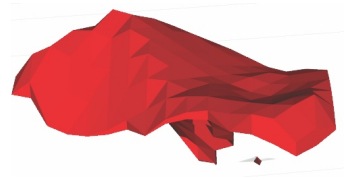

L-5

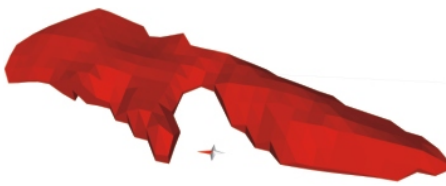

L-8

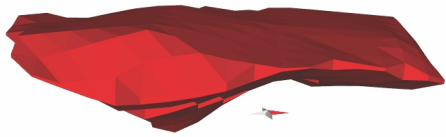

L-12

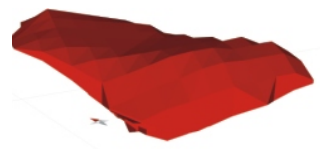

L-15

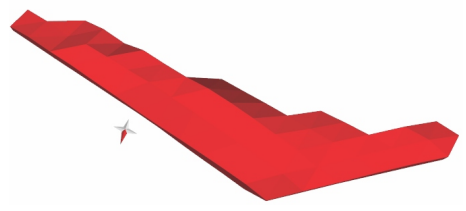

$\mathrm{L}-18$

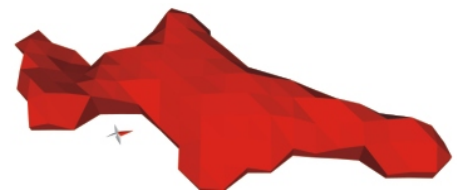

L-22

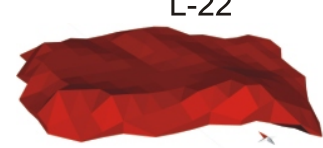

L-3

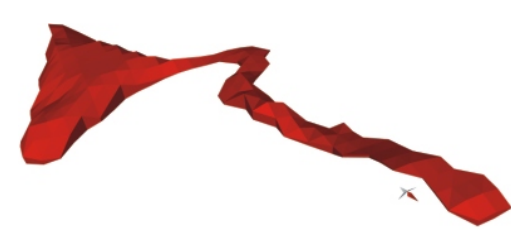

L-6
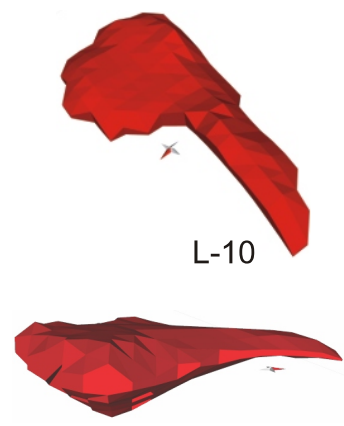

L-13

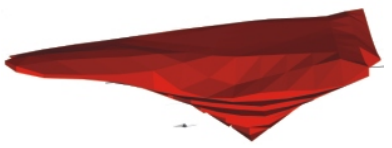

L-16

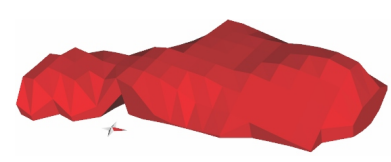

$\mathrm{L}-19$

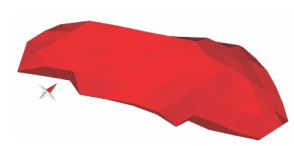

SB-1

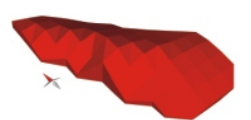

Fig. 18. 3D solid models of bauxite deposits

Acknowledgements. We are grateful to the Rudnici boksita Jajce company, Bosnia and Herzegovina, for support and permission to use the data necessary to conduct this research. The authors acknowledge the use of the Move Software Suite granted by Midland Valley's Academic Software Initiative. We are very grateful to the Midland Valley company for the donation of Move 2016 software with academic license to the University of Zagreb. Special thanks are addressed to the Geological Quarterly reviewers, Prof. A. Hoppe and Dr Z. Małolepszy for their constructive reviews that highly improved this paper. 


\section{REFERENCES}

Bárdossy, G., 1982. Karst Bauxites, Bauxite Deposits on Carbonate Rocks. Developments in Economic Geology, 14. Elsevier Scientific Publishing Company, Budapest.

Basson, I., Lourens, P., Paetzold, H-D., Thomas, S., Brazier, R. Molabe, P., 2017. Structural analysis and 3D modelling of major mineralizing structures at the Phalaborwa Copper Deposit. Ore Geology Review, 83: 30-42.

Caumon, G., Collon-Drouaillet, P., Le Carlier de Veslud, C. Viseur, S., Sausse, J., 2009. Surface-based 3D modelling of geological structures. Mathematical Geosciences, 41: 927-945.

Chilès, J.P., Aug, C., Guillen, A., Lees, T., 2004. Modelling the geometry of geological units and its uncertainty in 3D from structural data: the potential-field method. In: Proceedings of International Symposium on Orebody Modelling and Strategic Mine Planning, Perth, Australia: 313-320. Australasian Institute of Mining and Metallurgy (AusIMM).

Courrioux, G., Nullans, S., Guillen, A., Boissonnat, J.D., 2001. 3D volumetric modelling of Cadomian terranes (Northern Brittany, France): an automatic method using Voronoi diagrams. Tectonophysics, 331: 181-196.

De Kemp, E.A., 1999. Visualization of complex geological structures using 3-D Bezier construction tools. Computer and Geosciences, 25: 581-597.

De Kemp, E.A., 2000. 3D visualization of structural field data: examples from the Archean Caopatina Formation, Abitibi greenstone belt, Quebec, Canada. Computer and Geosciences, 26: 509-530.

De Kemp, E.A., Sprague, K.B., 2003. Interpretive tools for 3D structural geological modelling part I: Bézier based curves, ribbons and grip frames. Geolnformatica, 7/1: 55-71.

De Kemp, E.A., Schetselaar, E.M., Sprague, K., 2006. 3-D symbolization of $L-S$ fabrics as an aid to the analysis of geological structures. Computers and Geosciences, 32: 52-63.

Dhont, D., Luxey, P., Chorowicz, J., 2005. 3-D modelling of geologic maps from surface data. AAPG Bulletin, 89: 1465-1474.

Dragičević, I., 1981. Geological settings in bauxite bearing area Jajce, BiH (in Croatian). M.Sc. thesis, Faculty of Mining, Geology and Petroleum Engineering, University of Zagreb.

Dragičević, I., 1987. Paleogeographic evolution of margin of Mesozoic carbonate platform of Dinarides between Vrbas and Bosnia rivers (in Croatian). Ph.D. thesis, Faculty of Mining, Geology and Petroleum Engineering, University of Zagreb.

Dragičević, I., 1997. The bauxites of the northern margin of the Dinarides carbonate platform (area of Jajce, Bosnia). Travaux, 24: 64 .

Dragičević, I., Velić, I., 1994. Stratigraphical position and significance of reef facies at the northern margin of the Dinaric carbonate platform during the Late Jurassic and Cretaceous in Croatia and Bosnia. Géologie Méditerranéenne, 3-4: 59-63.

Dragičević, I., Velić, I., 2002. Northern margin of the Adriatic carbonate platform. Geologia Croatica, 55: 185-232.

Dragičević, I., Velić, I., 2006. Lithostratigraphic position of bauxite deposits in Bešpalje area (in Croatian). Archive of Geoeco-ing d.o.o., Zagreb.

Fernández, O., Muńoz, J.A., Arbués, P., Falivene, O., Marzo, M., 2004. Three-dimensional reconstruction of geological surfaces: an example of growth strata and turbidite systems from the Ainsa basin (Pyrenees, Spain). AAPG Bulletin, 88: 1049-1068.

Frank, T., Tertois, A-L., Mallet, J-L., 2007. 3D reconstruction of complex geological interfaces from irregularly distributed and noisy point data. Computers and Geosciences, 33: 932-943.

Galera, C., Tennis, C., Moretti, I., Mallet, J-L., 2003. Construction of coherent 3D geological blocks. Computers and Geosciences, 29: 971-984.

Husson, L., Mugnier, J.L., 2003. Three-dimensional horizon reconstruction from outcrop structural data, restoration, and strain filed of the Baisahi anticline, Western Nepal. Journal of Structural Geology, 25: 79-90.

Kaufman, O., Martin, T., 2008. 3D geological modelling from boreholes, cross-sections and geological maps, application over former natural gas storages in coal mines. Computers and Geosciences, 34: 278-290.

Ledru, P., 2001. The Cadomian crust of Britanny (France): 3D imagery from multisource data (Geófrance 3D). Tectonophysics, 331: 9-11.

Lemon, A.M., Jones, N.L., 2003. Building solid models from boreholes and user-defined cross-sections. Computers and Geosciences, 29: 547-555.

Mallet, J.L., 1992. Discrete smooth interpolation in geometric modelling. Computer-Aided Design, 24: 178-191.

Mallet, J.L., 1997. Discrete modelling for natural objects. Mathematical Geology, 29: 199-219.

Mallet, J.L., 2002. Geomodelling, Applied Geostatistics. Oxford University Press, New York.

Marinković, R., Ahac, A., 1975. Basic geological map of SFRY, sheet Jajce, scale 1:100,000 (in Croatian). Ssavezni Geološki Zavod, Beograd.

Marinković, R., Đorđević, D., 1975. Explanatory notes for Basic geological map of SFRY, sheet Jajce, scale 1:100,000 (in Croatian). Ssavezni Geološki Zavod, Beograd.

Martin-Izard, A., Arias, D., Arias, M., Gumiel, P., Sanderson, D.J., Castańon, C., Lavandeira, A., Sanchez, J., 2015. A new 3D geological model and structural evolution of the world-class Rio Tinto VMS deposit, Iberian Pyrite Belt (Spain). Ore Geology Reviews, 71: 457-476.

Maxelon, M., Mancktelow, N.S., 2005. Three-dimensional geometry and tectonostratigraphy of the Pennine zone, Central Alps, Switzerland and Northern Italy. Earth-Science Reviews, 71: 171-227.

Moro, A., Horvat, A., Tomić, V., Sremac, J., Bermanec, V., 2016. Facies development and paleoecology of rudists and corals: an example from Campanian transgressive sediments from northern Croatia, northeastern Slovenia and northwestern Bosnia. Facies, 62: 19.

Papeš, J., 1984. Geological Map of Bauxite Bearing Area Jajce BiH (in Croatian). Archive of Rudnici boksita Jajce d.d., Jajce.

Perrin, M., Zhu, Z., Rainaud, J.-F., Schneider, S., 2005. Knowledge-driven applications for geological modelling. Journal of Petroleum Science Engineering, 47: 89-104.

Popovs, K., Saks, T., Jātnieks, J., 2015. A comprehensive approach to the 3D geological modelling of sedimentary basins: example of Latvia, the central part of the Baltic Basin. Estonian Journal of Earth Sciences, 64: 173-188.

Schetselaar, E.M., 2013. Mapping the 3D lithofacies architecture of a VMS ore system on a curvilinear-faulted grid: a case study from the Flin Flon mining camp, Canada. Ore Geology Reviews, 53: $261-275$.

Sirakov, N.M., Muge, F.H., 2001. A system for reconstructing and visualizing 3D objects. Computers and Geosciences, 27: 59-69.

Sprague, K.B., de Kemp, E.A., 2005. Interpretive tools for 3-D structural geological modelling part II: surface design from sparse spatial data. Geolnformatica, 9: 5-32.

Tomić, V., 1983. Stratigraphy and paleogeography of Cretaceous-Paleogene bauxite bearing area Jajce, $\mathrm{BiH}$ (in Croatian). M.Sc. thesis, Faculty of Science, University of Zagreb.

Vanneschi, C., Salvini, R., Massa, G., Riccucci, S., Borsani, A., 2014. Geological $3 D$ modelling for excavation activity in an underground marble quarry in the Apuan Alps (Italy). Computers and Geosciences, 69: 41-54.

Wu, Q., Xu, H., Zou, X., 2005. An effective method for 3D geological modelling with multi-source data integration. Computers and Geosciences, 31: 35-43. 
Wycisk, P., Hubert, T., Gossel, W., Neumann, C., 2009. High-resolution 3D spatial modelling of complex geological structures for an environmental risk assessment of abundant mining and industrial megasites. Computers and Geosciences, 35 : 165-182.

Xue, Y., Sun, M., Ma, A., 2004. On the reconstruction of the three-dimensional complex geological objects using Delaunay triangulation. Future Generation Computer Systems, 20: 1227-1234.
Zanchi, A., Salvi, F., Zanchetta, S., Sterlacchini, S., Guerra, G., 2009. 3D reconstruction of complex geological bodies: examples from the Alps. Computers and Geosciences, 35/1: 49-69.

Zehnder, A.T., Allmendinger, R.W., 2000. Velocity field for the trishear model. Journal of Structural Geology, 22: 1009-1014

Zhu, L-F., He, Z., Pan, X., Wu, X-C., 2006. An approach to computer modelling of geological faults in $3 \mathrm{~d}$ and an application. Journal of China University of Mining and Technology, 16: 461-465. 